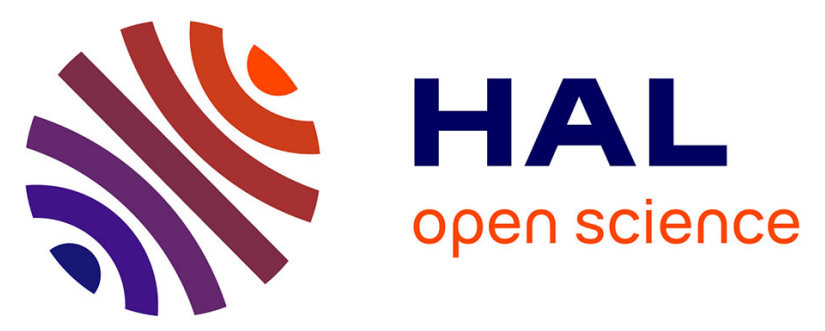

\title{
1,2-Dihydrophosphete: A Platform for the Molecular Engineering of Electroluminescent Phosphorus Materials for Light-Emitting Devices
}

Hui Chen, Simon Pascal, Zuoyong Wang, Pierre-Antoine Bouit, Zisu Wang, Yinlong Zhang, Denis Tondelier, Bernard Geffroy, Régis Réau, François Mathey, et al.

\section{To cite this version:}

Hui Chen, Simon Pascal, Zuoyong Wang, Pierre-Antoine Bouit, Zisu Wang, et al.. 1,2Dihydrophosphete: A Platform for the Molecular Engineering of Electroluminescent Phosphorus Materials for Light-Emitting Devices. Chemistry - A European Journal, 2014, 20 (31), pp.9784-9793. 10.1002/chem.201400050 . hal-01089789

\section{HAL Id: hal-01089789}

\section{https://hal-univ-rennes1.archives-ouvertes.fr/hal-01089789}

Submitted on 23 May 2016

HAL is a multi-disciplinary open access archive for the deposit and dissemination of scientific research documents, whether they are published or not. The documents may come from teaching and research institutions in France or abroad, or from public or private research centers.
L'archive ouverte pluridisciplinaire HAL, est destinée au dépôt et à la diffusion de documents scientifiques de niveau recherche, publiés ou non, émanant des établissements d'enseignement et de recherche français ou étrangers, des laboratoires publics ou privés. 


\title{
1,2-Dihydrophosphete: a new platform for the molecular engineering of electroluminescent P-materials for light-emitting devices
}

\author{
Hui Chen, ${ }^{[b]}$ Simon Pascal, ${ }^{[a]}$ Zuoyong Wang, ${ }^{[b]}$ Pierre-Antoine Bouit, ${ }^{[a]}$ Zisu Wang, ${ }^{[b]}$ Yinlong \\ Zhang, ${ }^{[b]}$ Denis Tondelier, ${ }^{[c]}$ Bernard Geffroy, ${ }^{[d]}$ Régis Réau, ${ }^{*[a]}$ François Mathey, ${ }^{* b]}$ Zheng \\ Duan, ${ }^{*[b]}$ Muriel Hissler, ${ }^{*[a]}$
}

\begin{abstract}
The discovery and molecular engineering of novel electroluminescent emitting materials is still a challenge in optoelectronics. In this work, we report on the development of new $\pi$-conjugated oligomers incorporating a dihydrophosphete skeleton. Variation
\end{abstract}

of the substitution pattern of 1,2dihydrophosphete derivatives and chemical modification of their $\mathrm{P}$ atoms afford thermally stable derivatives which are suitable emitters to construct organic light-emitting diodes. The optical and the electrochemical properties of these new P-based oligomers have been investigated in detail and are supported by DFT calculations. The OLED devices exhibit good performance and current independent CIE coordinates.

Keywords: Phosphorus, 1,2-
dihydrophosphete, $\pi$-systems,
OLED

\section{Introduction}

Organic light-emitting diodes (OLEDs) are key devices in the development of flat and flexible organic electronics. They have already been commercialized as components for displays and they have the potential for other promising applications such as solid state lighting. ${ }^{[1]}$ Despite the great success achieved by some commercial products in this area, the discovery and molecular engineering of novel electroluminescent emitting materials with improved electrical and optical properties are still relevant. With this aim, various heterocyclopentadienes (thiophene, silole...) have been

[a] Prof. M. Hissler, Prof. R. Réau, Dr P.-A. Bouit, S. Pascal, Institut des Sciences Chimiques de Rennes, UMR6226 CNRS-Université de Rennes 1, Campus de Beaulieu, 35042 Rennes Cedex, France E-mail: mhissler@univ-rennes1.fr,regis.reau@uni-rennes1.fr

[b] Prof. Z. Duan, Prof. F. Mathey, H. Chen, Z.Y. Wang, Z.S.Wang, Y.L. Zhang, College of Chemistry and Molecular Engineering, International Phosphorus Laboratory, Joint Research Laboratory for Functional Organophosphorus Materials of Henan Province, Zhengzhou University, Zhengzhou 450001, P. R. China

E-mail: duanzheng@zzu.edu.cn; fmathey@ntu.edu.sg

Prof. F. Mathey

Nanyang Technological University, CBC-SPMS, 21 Nanyang Link, Singapore 637371

E-mail: fmathey@ntu.edu.sg

[c] B. Geffroy

Laboratoire de Chimie des Surfaces et Interfaces, CEA Saclay, IRAMIS, SPCSI, 91191 Gif-sur-Yvette, Cedex, France

[d] D. Tondelier

Laboratoire de Physique des Interfaces et Couches Minces, CNRS UMR 7647, Ecole Polytechnique, 91128 Palaiseau, France

Supporting information for this article is available on the WWW under http://www.chemeurj.org/ or from the author.

incorporated into the backbone of $\pi$-conjugated systems since their electronic properties are dependent on the nature of the heteroatom. For example, phospholes have received particular attentions as building blocks for the tailoring of functional $\pi$-conjugated systems for optoelectronic applications. ${ }^{[2]}$ One appealing property of this five-membered heterocycle is that simple chemical modifications of the reactive phosphorus center allow a tuning of the HOMO and LUMO levels, an improvement of the thermal stability, and a control of the solid state organisation of the $\pi$-systems, providing a simple and direct method for diversifying the structure and properties. This unique way of $\pi$-system molecular engineering afforded efficient materials for OLEDs, including white-emitting devices. ${ }^{[3]}$ These results prompted us to prepare and study the physical properties of other phosphacycles as building blocks for electroluminescent $\pi$-conjugated materials. Phosphorus heterocyclic chemistry is nowadays well-developed and many types of $\pi$ derivatives (4-,5-,6-,7-membered rings; presence of several heteroatoms...) are easily available on gram-scale. ${ }^{[4]}$ Among this diversity of structures, we focussed on the 1,2-dihydrophosphete skeleton for the development of $\pi$-conjugated materials for several reasons. This unsaturated building block has been known since the 80 's, and its synthesis and reactivity have been widely investigated making this type of heterocycle easily accessible and wellunderstood. ${ }^{[5]}$ Within this family of P rings, 2-(diphenylmethylene)1,4-diphenyl-1,2-dihydrophosphete skeleton (molecule 2a-f, Scheme 1) appeared to us as an original platform for the development of novel P-materials for optoelectronic applications. Firstly, it possesses a $\pi$-conjugated system interacting with a phosphorus atom within a four-membered unsaturated ring. It was thus of interest to investigate the impact of P-modifications for tuning the electronic properties of this $\pi$-system. Note that the optical and electrochemical properties of this family of Pheterocycles have never been investigated. Secondly, the pyramidal shape of the P-atom affords steric hindrance which is a key parameter for solid-state engineering of chromophores since it should prevent the aggregation phenomena from taking place. Lastly, straightforward synthesis of phosphetes allowing easy derivatization are known and these rings appear to exhibit quite high chemical and thermal stability.

In this paper, we report on the synthesis of a new family of 1,2-dihydrophosphete derivatives 3a-f, 4a, 5a (Scheme 1) and elucidation of their photophysical, thermal and electrochemical properties by following UV-Vis, photoluminescence, cyclovoltammetry, thermogravimetric analysis (TGA) and differential scanning calorimetry (DSC) studies. The use of these P- 
rings as emitting materials in OLED devices is reported. These devices emit in the blue-green region, illustrating the potential of this novel P-platform for the development of materials for molecular electronics.

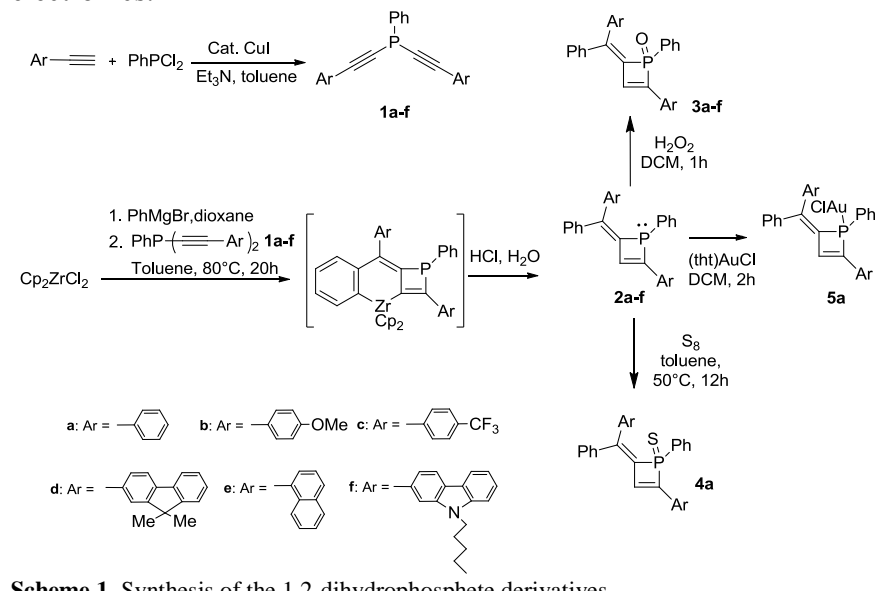

\section{Results and Discussion}

1,2-Dihydrophosphete derivatives 2a-f were synthesized according to a straightforward one pot - four step procedure, devised by Majoral et al..$^{\left[5^{\mathrm{e}}\right]}$ (Scheme 1), involving an intramolecular coupling reaction of a dialkynylphosphane and zirconocene-benzene (Scheme 1). The starting materials 1a-f $\left({ }^{31} \mathrm{P}\right.$ NMR: $\delta=$ ca. $\left.-60 \mathrm{ppm}\right)$ were obtained in medium to good yields (47-83\%) via copper-catalyzed cross-coupling of terminal alkynes with dichlorophenylphosphine (Scheme 1). ${ }^{[6]}$ The presence of the Ph-substituents on the P-atom is essential for providing good solubility and stability to these derivatives. They were reacted with the transient benzyne complex, generated in situ by thermolysis of a solution of $\left[\mathrm{Cp}_{2} \mathrm{ZrPh}_{2}\right]$ in toluene at $80^{\circ} \mathrm{C}$, resulting in the formation of the corresponding benzo-zirconacyclohexadiene-phosphabutenes which upon treatment in acidic media gave access to the expected 1,2dihydrophosphetes 2a-f $\left({ }^{31} \mathrm{P}\right.$ NMR: $\delta=c a .+22.0 \mathrm{ppm}$ ) (Scheme 1). $.5^{\mathrm{e}-\mathrm{g}]}$ Since the trivalent $\mathrm{P}$-atom of 1,2-dihydrophosphetes is sensitive to oxidation, they were readily transformed into the $\sigma^{4}$ derivatives 3a-f, 4a and 5a by treatment with hydrogen peroxide, elemental sulfur and (tetrahydrothiophene) $\mathrm{AuCl}$, respectively (Scheme 1). $2^{\text {] }}$ These compounds were purified by column chromatography and isolated as air-stable powders in good yields (34\%-58\%). The newly prepared P-compounds 1b-f, 3a-f, 4a and 5a were characterized by high-resolution mass spectrometry, elemental analysis, and their multinuclear NMR spectroscopic data support the proposed structures. It is noteworthy that this synthetic route is rather simple and efficient, allowing both gram-scale preparation and introduction of a large variety of functional groups (electronwithdrawing and electron-donating substituents) on the organophosphorus backbone through functionalization of the starting dialkynylphosphanes $\mathbf{1}$ (Scheme 1). Furthermore, Pfunctionalization allows additional straightforward derivatization $(\mathrm{P}=\mathrm{O}, \mathrm{P}=\mathrm{S}, \mathrm{P}-\mathrm{AuCl})$ of these $\pi$-conjugated platforms.

The structure of the gold complex 5a was investigated by $\mathrm{X}$ ray crystallography in order to gain insight into the organization of the phosphete derivatives in the solid state (Figure 1). Single crystals of 5a suitable for X-ray diffraction study were grown upon diffusion of pentane into a dichloromethane solution. The metric data of the phosphete-AuCl subunit are classical (Table 1). ${ }^{[3 \mathrm{e}]}$ For

example, the phosphorus center adopts a distorted tetrahedral geometry $\left(\sum \mathrm{P}_{\text {ang }}=294.8^{\circ}\right)$ and the endocyclic $\mathrm{P}-\mathrm{C}$ bond lengths

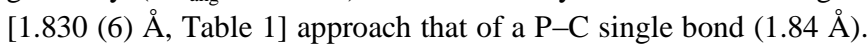
The geometry around $\mathrm{Au}$ atom is almost linear $(\mathrm{P}-\mathrm{Au}-\mathrm{Cl}, 178.69$ $\left.(6)^{\circ}\right)$. The $\pi$-conjugated backbone including the dihydrophosphete ring and the substituents in position 2 and 4 (exocyclic double bond and phenyl ring) are planar (maximum deviation from the mean $\mathrm{C}$ $s p^{2}$ plane, $\left.0.06 \AA\right)$ and the $\mathrm{C}-\mathrm{C}$ bond lengths $\left(\mathrm{d}_{\mathrm{C} 3-\mathrm{C} 4}=1.455\right.$ (8) $\AA$, $\mathrm{d}_{\mathrm{C} 1-\mathrm{C} 2}=1.462$ (9) $\AA$, Figure 1) between the double bonds are in the range expected for $\left(\mathrm{C}\left(\mathrm{sp}^{2}\right)-\mathrm{C}\left(\mathrm{sp}^{2}\right)\right)$ single bonds. These data indicate the presence of an extended $\pi$ conjugation including the endocyclic double bond of the phosphete and the substituents in the 2- and 4positions (exocyclic double bond and phenyl ring). Note that the two lateral phenyl substituents of the $\mathrm{C} 10$ atom (Figure 1) are twisted with respect to this main $\mathrm{C}-s p^{2}$ plane (twist angles, $44.2^{\circ}$ and $59.2^{\circ}$ ) due to $\mathrm{H}-\mathrm{H}$ repulsion.

The solid-state organization of complex 5a (Figure 1) shows no intermolecular $\pi-\pi, \mathrm{CH}-\pi$ or aurophilic $(\mathrm{d}(\mathrm{Au}-\mathrm{Au})>5.3 \AA)$ interactions. This property is likely due to the presence of out-of $\mathrm{Cp}^{2}$-planes substituents ( $\mathrm{P}$-and $\mathrm{C} 10$-substituents) which provide steric hindrance. This property is promising in the prospect of using these compounds as emitters in OLEDs since aggregation of emitting materials is known to reduce the efficiency of these devices.
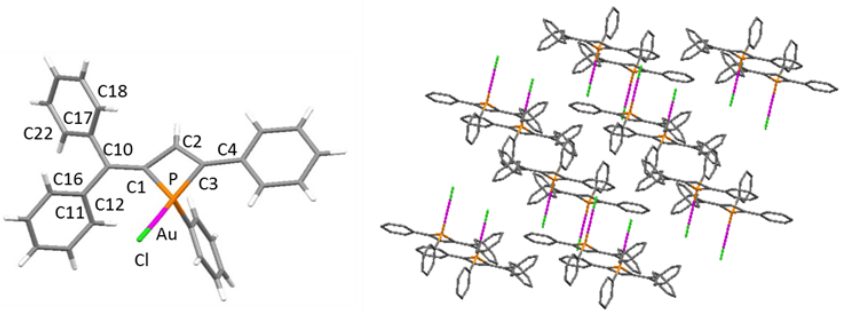

Figure 1. Structure and packing of the gold complex $\mathbf{5 a}$ in the solid state

Table 1 Selected bond lengths $[\AA ̊]$ and twist angles between the phosphete ring and its 2- and 4-Substituents $\left[{ }^{\circ}\right]$ for the gold complex $\mathbf{5 a}$.

\begin{tabular}{cccc}
\multicolumn{2}{c}{ Bond length } & \multicolumn{2}{c}{ Angles } \\
\hline $\mathrm{P}-(\mathrm{C} 1)$ & $1.830(6)$ & $(\mathrm{C} 1)-\mathrm{P}-(\mathrm{C} 3)$ & $74.5(3)$ \\
$(\mathrm{C} 1)-\mathrm{C} 2)$ & $1.462(9)$ & $(\mathrm{C} 1)-\mathrm{P}-(\mathrm{C} 23)$ & $115.2(2)$ \\
$(\mathrm{C} 2)-(\mathrm{C} 3)$ & $1.363(8)$ & $\mathrm{C}(1)-\mathrm{P}-\mathrm{Au}$ & $119.4(2)$ \\
$(\mathrm{C} 3)-\mathrm{P}$ & $1.829(6)$ & $(\mathrm{C} 3)-\mathrm{P}-(\mathrm{C} 23)$ & $107.3(3)$ \\
$\mathrm{P}-\mathrm{Au}$ & $2.2237(19)$ & $\mathrm{C}(3)-\mathrm{P}-\mathrm{Au}$ & $120.9(2)$ \\
$\mathrm{Au}-\mathrm{Cl}$ & $2.291(2)$ & $\mathrm{C}(23)-\mathrm{P}-\mathrm{Au}$ & $115.2(2)$ \\
$(\mathrm{C} 1)-(\mathrm{C} 10)$ & $1.349(8)$ & $\mathrm{P}-\mathrm{Au}-\mathrm{Cl}$ & $178.69(7)$ \\
$(\mathrm{C} 3)-(\mathrm{C} 4)$ & $1.455(8)$ & & \\
\hline
\end{tabular}

In order to establish the structure-property relationship for this novel series of P-based $\pi$-conjugated systems (Scheme 1), their UVvis absorption, excitation and fluorescence spectra were measured in $\mathrm{CH}_{2} \mathrm{Cl}_{2}$ (Table 2). It is noteworthy that the polarity and the hydrogen-bond donor ability (HDBA) of the solvent have a negligible effect on the absorption and emission properties and the UV-vis absorption maxima are in very good agreement with the excitation data (see SI, Figure S1-4).

Table 2. Photophysical, electrochemical and thermal data for 3a-f, 4a, 5a.

\begin{tabular}{cccccccc}
$\begin{array}{c}\lambda_{\max } \\
\left.[\mathrm{nm}]^{[\mathrm{a}]}\right]\end{array}$ & $\begin{array}{c}\varepsilon \\
{\left[\mathrm{M}^{-1} \cdot \mathrm{cm}^{-1}\right]}\end{array}$ & $\begin{array}{c}\lambda_{\text {em }} \\
{[\mathrm{nm}]^{[\mathrm{a}]}}\end{array}$ & $\begin{array}{c}\Phi_{\mathrm{f}} \\
(\%)^{[\mathrm{b}]}\end{array}$ & $\begin{array}{c}\mathrm{T}_{\mathrm{TGA}} \\
{\left[{ }^{\circ} \mathrm{C}\right]^{[\mathrm{c}]}}\end{array}$ & $\begin{array}{c}\mathrm{T}_{\mathrm{m}} \\
{\left[{ }^{\circ} \mathrm{C}\right]^{[\mathrm{d}]}}\end{array}$ & $\begin{array}{c}E_{\text {ox }}^{1} \\
{[\mathrm{~V}]^{[\mathrm{e}]}}\end{array}$ & $\begin{array}{c}E_{\text {red }}^{1} \\
{[\mathrm{~V}]^{[\mathrm{e}]}}\end{array}$ \\
\hline 358 & 36900 & 426 & 2.4 & 316 & 205 & - & -2.19
\end{tabular}




\begin{tabular}{cccccccccc}
\hline $\mathbf{3 b}$ & 375 & 36800 & 445 & 1.6 & 320 & 75 & $+0.76^{[\mathrm{h}]}$ & $-^{[\mathrm{f}]}$ \\
\hline $\mathbf{3 c}$ & 360 & 30100 & 426 & 0.6 & 300 & 165 & $-^{[\mathrm{f}]}$ & $-1.87^{[\mathrm{h}]}$ \\
\hline $\mathbf{3 d}$ & 400 & 50000 & $458 / 480$ & 6.6 & 375 & 230 & $+0.79^{[\mathrm{h}]}$ & $-2.09^{[\mathrm{h}]}$ \\
\hline $\mathbf{3 e}$ & 375 & 33200 & 456 & 5.2 & 340 & $-{ }^{[\mathrm{f}]}$ & +1.19 & -2.14 \\
\hline $\mathbf{3 f}$ & 409 & 36200 & 483 & 12.4 & 345 & $-[\mathrm{f}]$ & $+0.49^{[\mathrm{h}]}$ & -2.46 \\
\hline $\mathbf{4 a}$ & 358 & 27700 & 421 & 0.5 & 330 & 152 & +1.03 & $-2.13^{[\mathrm{h}]}$ \\
\hline $\mathbf{5 a}$ & 359 & 33200 & 425 & 0.9 & 300 & 130 & +1.15 & -2.09 \\
\hline
\end{tabular}

[a] Measured in $\mathrm{CH}_{2} \mathrm{Cl}_{2}\left(5.10^{-5} \mathrm{M}\right)$. [b] Measured relative to quinine sulfate $\left(\mathrm{H}_{2} \mathrm{SO}_{4}, 0.1\right.$ $\mathrm{M}), \pm 15 \%$. [c] Onset weight-loss temperature estimated using TGA under nitrogen. [d] Melting point measured by DSC under Argon, $10^{\circ} \mathrm{C} / \mathrm{min}$. [e] All potentials were obtained during cyclic voltammetric investigations in $0.2 \mathrm{M} \mathrm{Bu}_{4} \mathrm{NPF}_{6}$ in $\mathrm{CH}_{2} \mathrm{Cl}_{2}$. Platinum electrode diameter $1 \mathrm{~mm}$, sweep rate: $200 \mathrm{mV} \mathrm{s}^{-1}$. All potentials are referenced to the reversible formal potential of ferrocene/ferrocenium. [f] not observed $[\mathrm{h}]$ reversible process.

Compounds 3-5a display an intense band in the UV-visible region centered at $358 \mathrm{~nm}$, attributed to $\pi-\pi^{*}$ transitions of the extended $\pi$-conjugated system including the dihydrophosphete ring and substituents in position 2 and 4 (exocyclic double bond and phenyl ring). Interestingly, these derivatives exhibit blue emissions (Figure 2) albeit with low quantum yields $\left(\Phi_{\mathrm{f}}=0.5-2 \%\right.$, Table 2$)$. The presence of the "bridging phosphorus atom" impacts the optical properties compared to the 1,1,4-triphenylbutadiene. ${ }^{[7]}$ Due to a partial rigidification of the $\pi$-system, red-shifted structured absorption and emission bands are observed for the dihydrophosphete compound, suggesting a better electron delocalization along the $\pi$-system and a small rearrangement of these molecules upon photoexcitation. In return, the substituent on the P-atom has a very weak impact on the optical transitions but clearly impacts the quantum yield, with best performance for the $\mathrm{P}=\mathrm{O}$ derivative 3a (Table 2). Interestingly, the introduction of electron-rich substituents (3b) induces a bathochromic shift of absorption and emission maxima while the introduction of electron deficient substituents (3c) has no impact on the optical properties. This effect is attributed to an intramolecular charge transfer from the electron-donating group to the electron-deficient dihydrooxophosphete center. Moreover, upon extension of the $\pi$-conjugated system, all optical features are significantly red-shifted from those of compound 3a (Table 2). The smallest bathochromic shift is observed with the naphthalene substituted oligomer $3 \mathbf{e}\left(\lambda_{\text {abs }}=375\right.$ $\left.\mathrm{nm}, \lambda_{\mathrm{em}}=456 \mathrm{~nm}\right)$. The fluorene and the carbazole substituted oligomers (3d, 3f) show significantly red-shifted maxima of absorption and emission $\left(\mathbf{3 d}, \lambda_{\mathrm{abs}}=400 \mathrm{~nm}, \lambda_{\mathrm{em}}=468 \mathrm{~nm} ; \mathbf{3 f}, \lambda_{\mathrm{abs}}=\right.$ $409 \mathrm{~nm}, \lambda_{\mathrm{em}}=483 \mathrm{~nm}$ ) indicating an increased effective conjugation length in both molecules compared to the compound 3a. Furthermore, Compounds 3d-f display an emission band in the 460$480 \mathrm{~nm}$ range with moderate quantum yield in solution $\left(5 \%<\Phi_{\mathrm{f}}<\right.$ $12 \%$ ) making them a good candidate to act as blue emitter in OLED devices.

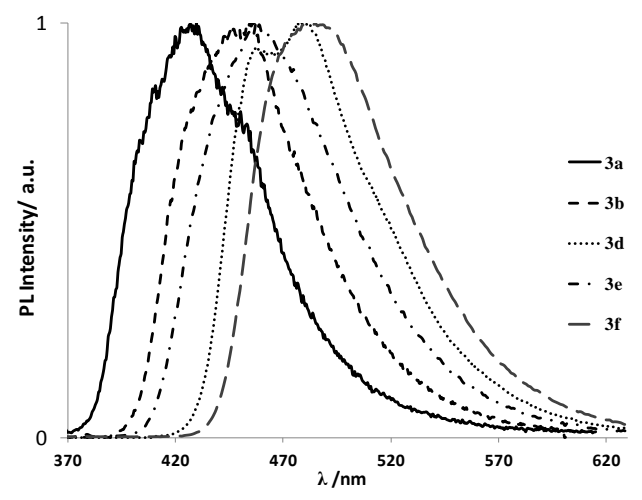

Figure 2. Normalized emission spectra of $\mathbf{3 a}, \mathbf{b}, \mathbf{d}, \mathbf{e}, \mathbf{f}$ recorded in dichloromethane $\left(5.10^{-6} \mathrm{M}\right)$.

In order to gain a deeper understanding of the electronic structure of these phosphete derivatives (Figure 3), DFT calculations at the B3LYP/6-31+G(d, p) level were carried out to obtain orbital distributions of the highest occupied molecular orbitals (HOMO, HOMO-1) and the lowest unoccupied molecular orbital (LUMO) energy levels. As shown in Figure 3, the calculated optimized structure of derivative 2a shows that the $\pi$-conjugated backbone, including the dihydrophosphete ring and substituents in position 2 and 4 (exocyclic double bond and phenyl ring), is planar and is similar to the structure of 5a (Figure 1). The HOMO and the LUMO energy levels are localized on the entire $\pi$-conjugated carbon framework and the contribution of the phosphorus lone pair is mainly localized in the HOMO-1. Since the difference in energy between the HOMO-1 and HOMO is significant and neither the HOMO nor the LUMO show a sizeable localization at phosphorus, the chemical modifications on the phosphorus atom will have negligible impact on the HOMO-LUMO gap, as observed by UVvis absorption.
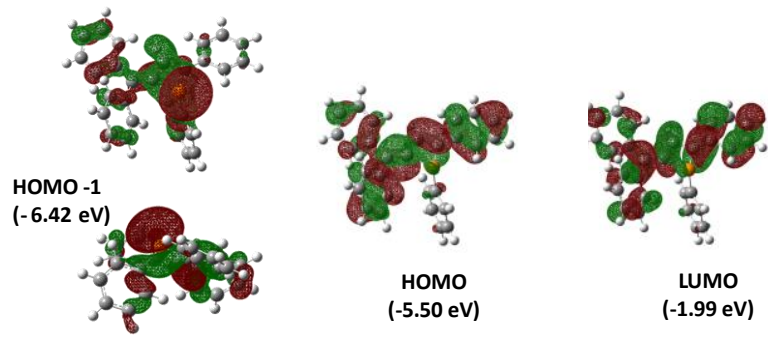

Figure 3. Calculated molecular orbital amplitude plots of HOMO -1, HOMO and LUMO levels of $\mathbf{2 a}$.

The impact of these chemical modifications performed on the P-atom (3a) or on the $\pi$-system by introduction of electron rich or deficient substituents (3b and $\mathbf{3 c}$ respectively) on the molecular orbital levels has also been rationalized by DFT calculations. As observed for 2a (vide supra), the computed molecular orbitals of 3ac are fully delocalized over the entire backbone. The oxidation of $\mathrm{P}$ atom induces a stabilization of the molecular orbital levels as well as a reduction of the HOMO-LUMO gap (see Figure S5 and Figure 3). The introduction of electron-rich substituents on the $\pi$-system induces a reduction of the HOMO-LUMO gap by a pronounced increase of the HOMO energy level of $\mathbf{3 b}$ while the introduction of electron withdrawing group (3c) stabilizes in a similar manner the HOMO and the LUMO level inducing no reduction of the HOMO- 
Table 3. El performance of devices as function of the device structure and the doping rate

\begin{tabular}{|c|c|c|c|c|c|c|}
\hline \multirow[t]{2}{*}{ Device $^{[a]}$} & $\mathrm{EML}^{[\mathrm{b}]}$ & $\lambda_{\max }^{\mathrm{EL}}$ & $\begin{array}{l}\text { External } \\
\text { quantum } \\
\text { efficiency }\end{array}$ & $\begin{array}{c}\text { Current } \\
\text { efficiency }^{[\mathrm{c}]}\end{array}$ & $\begin{array}{c}\text { Power } \\
\text { efficiency }^{[\mathrm{c}]}\end{array}$ & $\begin{array}{c}\text { CIE } \\
\text { coordinates }\end{array}$ \\
\hline & Doping rate [wt. \%] & {$[\mathrm{nm}]$} & [\%] & {$\left[\mathrm{cd} \mathrm{A}^{-1}\right]$} & {$\left[\operatorname{lm~W} \mathrm{W}^{-1}\right]$} & $(\mathrm{x}, \mathrm{y})$ \\
\hline $\mathbf{A}$ & 3d & $468 / 505$ & 0.9 & 2.2 & 0.6 & $(0.27,0.46)$ \\
\hline B & CBP:3d (2.5\%) & 492 & 0.7 & 1.3 & 0.4 & $(0.17,0.32)$ \\
\hline $\mathbf{C}$ & DPVBi:3d (2.5\%) & 492 & 2.5 & 5.1 & 1.4 & $(0.18,0.34)$ \\
\hline D & CBP:3e $(2.7 \%)$ & 476 & 0.4 & 0.6 & 0.2 & $(0.16,0.24)$ \\
\hline $\mathbf{E}$ & DPVBi:3e (1.3\%) & 474 & 1.6 & 2.8 & 0.8 & $(0.17,0.27)$ \\
\hline $\mathbf{F}$ & DPVBi:3e (2.3\%) & 480 & 1.4 & 2.6 & 0.7 & $(0.18,0.29)$ \\
\hline $\mathbf{G}$ & DPVBi:3e (7.2\%) & 484 & 1.1 & 2.3 & 0.7 & $(0.20,0.32)$ \\
\hline $\mathbf{H}$ & DPVBi:3f $(1.6 \%)$ & 488 & 1.2 & 2.3 & 0.6 & $(0.18,0.31)$ \\
\hline $\mathbf{I}$ & DPVBi:3f $(4.0 \%)$ & 500 & 1.1 & 2.4 & 0.7 & $(0.20,0.39)$ \\
\hline ref & DPVBi & 468 & 2.1 & 3.2 & 0.9 & $(0.16,0.22)$ \\
\hline
\end{tabular}

[a] Device configuration (thickness): ITO/CuPc $(10 \mathrm{~nm}) / \alpha-\mathrm{NPB}(50 \mathrm{~nm}) / \mathrm{EML}(15 \mathrm{~nm}) / \mathrm{DPVBi}(35 \mathrm{~nm}) / \mathrm{BCP}(10 \mathrm{~nm}) / \mathrm{Alq}{ }_{3}(50 \mathrm{~nm}) / \mathrm{LiF}(1.2 \mathrm{~nm}) / \mathrm{Al}(100 \mathrm{~nm}) ;[\mathrm{b}] \mathrm{EML}(\mathrm{Emitting}$ Layer) $=\mathrm{P}$-emitter, DPVBi or CBP as host $[\mathrm{c}]$ Measured at $20 \mathrm{~mA} / \mathrm{cm}^{2}$

LUMO gap (see Figure S5). All these assumptions are nicely supported by the optical and the electrochemical data.

Cyclic voltammetry $(\mathrm{CV})$, recorded in $\mathrm{CH}_{2} \mathrm{Cl}_{2}$ using $\mathrm{Bu}_{4} \mathrm{NPF}_{6}$ as electrolyte, was used to investigate the redox properties of 3a-f, 4a and 5a (Table 2). Compounds 3-5a display different electrochemical behaviours depending on the P-substitution. Compound 3a presents only an irreversible electronic reduction wave $\left(\mathrm{E}_{\text {red1 }}^{\circ}=-2.19 \mathrm{~V}\right.$ vs. $\left.\mathrm{Fc}^{+} / \mathrm{Fc}\right)$ in the electrochemical window. While replacing $\mathrm{O}$ by $\mathrm{S}$ in $\mathbf{4 a}$, an irreversible electronic oxidation wave is observed $\left(\mathrm{E}^{\circ}{ }_{\mathrm{ox1}}=+1.03 \mathrm{~V}\right.$ vs. $\left.\mathrm{Fc}^{+} / \mathrm{Fc}\right)$ and the reduction becomes reversible $\left(\mathrm{E}_{\text {red1 }}^{\circ}=-2.13 \mathrm{~V}\right.$ vs. $\left.\mathrm{Fc}^{+} / \mathrm{Fc}\right)$. Coordination to $\mathrm{Au}(\mathrm{I})$ slightly modifies the potentials (see Table 3) while keeping the electrochemical gap constant (around $3.0 \mathrm{eV}$ ). All these observations demonstrate that chemical modifications performed at the P-atom impact weakly the HOMO and LUMO's energy of the phosphete compounds. As anticipated, introduction of electrondonating groups cathodically shifts the oxidation wave $\left(\mathrm{E}^{\circ}{ }_{\text {ox } 1}=\right.$ $+0.76 \mathrm{~V}$ vs. $\mathrm{Fc}^{+} / \mathrm{Fc}$ for $3 \mathbf{b}$ ) while the introduction of electron withdrawing group anodically shifts the reduction wave $\left(\mathrm{E}^{\circ}\right.$ red1 $=$ $1.87 \mathrm{~V}$ vs. $\mathrm{Fc}^{+} / \mathrm{Fc}$ for $3 c$ ). Furthermore, the introduction of emissive subunits like fluorene (3d), naphthalene (3e) or carbazole (3f) also affects the redox potential. For example, compound 3d displays amphoteric redox character with quasi-reversible electrochemical waves (see Table 2) making it appealing for application in optoelectronic devices. This study clearly shows that modifications of both $\pi$-conjugated system and P-environment impact the electrochemical properties of the compounds and allow fine tuning of its bandgap.

Interestingly, dihydrophosphete derivatives 3a-f, 4a and 5a display excellent thermal stability (Table 2). Thermogravimetric analyses (TGA) measurements performed under nitrogen atmosphere show that the whole family of compounds display decomposition temperatures above $300^{\circ} \mathrm{C}$, which allows them to be used in "small molecule" OLEDs technology. Particularly, fluorene- substituted compound 3d shows a decomposition temperature at $10 \%$ weight loss $\left(\mathrm{Td}_{10}\right)$ of $375{ }^{\circ} \mathrm{C}$. Differential scanning calorimetry (DSC) measurements show that their melting points $(\mathrm{Tm})$ were in the range of $75-230^{\circ} \mathrm{C}$ (Table 2). The formation of a glassy state of these derivatives after melting and cooling was evidenced (for example, $T g$ (3d): $127{ }^{\circ} \mathrm{C}$ ). Further heating above the glass transition temperature and cooling down to $25^{\circ} \mathrm{C}$ resulted in no further crystallization or melting behaviors. These results indicate that they present good morphological and thermal stabilities, two critical issues for operating stability and lifetime of the devices.

Since the derivatives 3d-f (Scheme 1) are thermally stable and emissive (Table 2), they can be used as emitters in multilayer OLEDs. First, compound 3d was used as a pure emitting layer (EML) in multilayer OLED A (Table 3) having an indium tin oxide (ITO)/ copper phthalocyanine (CuPc) $(10 \mathrm{~nm}) / \mathrm{N}, \mathrm{N}$ '-diphenylN,N'-bis(1-naphthylphenyl)-1,1'-biphenyl-4,4'-diamine $\quad(\alpha-\mathrm{NPB})$ $(50 \mathrm{~nm})$ / EML (15 nm) / 4,4'-bis(2,2'-diphenylvinyl)biphenyl (DPVBi) (35 nm) / bathocuproine (BCP) (10 nm) / tris $(8$ hydroxyquinolinato)aluminium $\left(\mathrm{Alq}_{3}\right)(50 \mathrm{~nm}) / \mathrm{LiF}(1.2 \mathrm{~nm}) / \mathrm{Al}$ $(100 \mathrm{~nm})$ configuration (see Figure S6). The electroluminescence (EL) spectrum of device $\mathbf{A}\left(\lambda_{\operatorname{maxEL}}=500 \mathrm{~nm}\right)$ resembles the thin film PL spectrum of derivative $\mathbf{3 d}\left(\lambda_{\mathrm{em}}=502 \mathrm{~nm}\right)$ showing that the EL emission bands are from this P-luminophore. Furthermore the increase of the current density does not impact the emission wavelength of device A (Figure 4), proving that this emission is not due to degradation of the material. The luminance of this device reaches $1000 \mathrm{~cd} . \mathrm{m}^{-2}$ at $20 \mathrm{~mA} \cdot \mathrm{cm}^{-2}$ with current and power efficiencies of $2.19 \mathrm{~cd} . \mathrm{A}^{-1}$ and $0.61 \mathrm{~lm} . \mathrm{W}^{-1}$, respectively (Table 3). These moderate performances have been assigned to the moderate charge carrier conduction properties of the EML. In order to improve the device performance, we incorporated the P-fluorophore 3d in two matrices having similar HOMO and LUMO energy levels but different charge transport properties: 4,4'-bis(2,2'diphenylvinyl)biphenyl (DPVBi) and $4,4^{\prime}-N, N^{\prime}$-dicarbazolebiphenyl (CBP). CBP possesses a hole mobility at least one order of magnitude higher than its electron mobility ${ }^{[8]}$ and DPVBi is usually used as blue emitter matrix and electron transporting layer (ETL) in OLEDs. ${ }^{[9]}$ For a doping rate (DR) of $2.5 \%$, the EL spectrum of the devices B (CBP matrix) and C (DPVBi matrix) exhibit only the characteristic emission of the P-derivative $\mathbf{3 d}$, no emission of the matrix is observed but the performance of these diodes is affected by the nature of the host material (Table 3). The device $\mathbf{C}$ using DPVBi as host exhibits much higher efficiencies compared to the device B using CBP matrix. Effectively, the external quantum efficiency, current and power efficiencies have been multiplied by $\approx$ 4. This effect can be explained by a better charge transport as shown in Figure 5 where the $\mathrm{J}-\mathrm{V}$ curve for the device $\mathbf{C}$ comprising DPVBi as host is shifted to lower voltages comparatively to device $\mathbf{B}$ (CBP 
matrix). Furthermore the performance of device $\mathbf{C}$ is very satisfying with a brightness of $3000 \mathrm{~cd} \cdot \mathrm{m}^{-2}$ at $20 \mathrm{~mA} / \mathrm{cm}^{2}$ (Figure S9). Moreover, the brightness regularly increases with the current density (see SI) showing the good stability of this OLED. Similar observation has been made with P-fluorophore 3e (Table 3, Figure S10-11), only the EL emission maximum has been blue -shifted $\left(\lambda_{\mathrm{em}}=474 \mathrm{~nm}\right.$, Table 3 ) compared to device $\mathbf{C}$ due to the presence of the naphthalene substituents. Since the device with DPVBi host had the best performance, we decided to keep the DPVBi matrix for studying the effect of the doping ratio on the EL performance when compounds $\mathbf{3 e}$ and $\mathbf{3 f}$ were used as emitters. As it can be seen in Table 3 (devices $\mathbf{E}, \mathbf{F}, \mathbf{G}, \mathbf{H}$ and $\mathbf{I}$ ) the performance of the devices is not changed by an increase of the doping ratio. Even for high doping ratio (device $\mathbf{G}$ ) the quenching effect is limited due to the particular property of the P-molecules avoiding the formation of strong aggregates ${ }^{[3 b]}$. The increase of the doping rate induces only a small variation of the EL emission wavelength and on the CIE coordinates.

In summary, all the P-fluorophores present a greenish-blue emission. The best performance has been obtained for $\mathbf{3 d}$ used as dopant in a DPVBi host (device $\mathbf{C}$ ) with a current efficiency up to $5.1 \mathrm{~cd} / \mathrm{A}$, which is fairly good for a fluorescent blue emitter. It is worthy to note that this value is higher than for the reference blue device with DPVBi as emitter (device ref, Table 3).

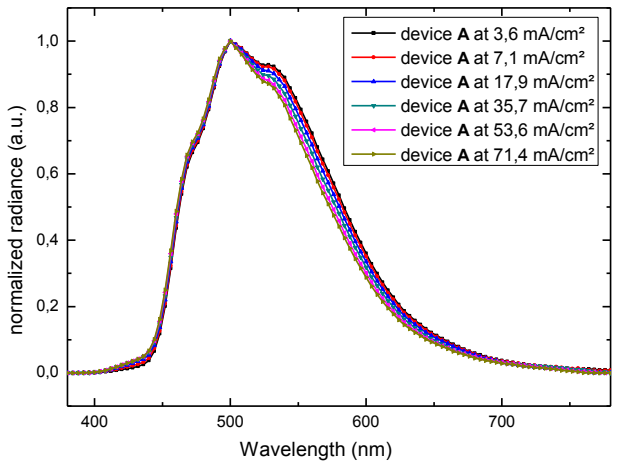

Figure 4. EL emission spectra of the diode $\mathbf{A}$ at different current densities.

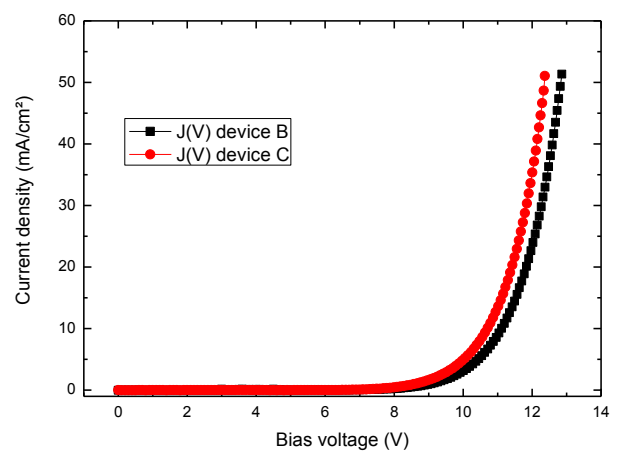

Figure 5. J-V characteristics of devices $\mathbf{B}$ and $\mathbf{C}$

\section{Conclusion}

In conclusion, the 1,2-dihydrophosphete skeleton is an interesting building block for the development of new $\pi$-conjugated oligomers. Variation of the substitution pattern of 1,2-dihydrophosphete derivatives and chemical modification of their $\mathrm{P}$ atoms afford thermally stable derivatives which are suitable emitters to construct efficient organic light emitting diodes. For example, OLEDs containing the phosphete-based compound $\mathbf{3 d}$ as emitter exhibit blue electroluminescence, good performances and current independent CIE coordinates.

\section{Experimental Section}

General Procedures. All experiments were performed under an atmosphere of dry nitrogen using standard Schlenk techniques. Column chromatography was performed in air, unless stated in text. Solvents were freshly distilled under nitrogen from sodium/benzophenone (tetrahydrofurane, diethylether) or from phosphorus pentoxide (dichloromethane, toluene). All reagents were used as received and used directly without further purification. Silica gel (200-300 mesh) for purification and silica gel TLC (F254) were purchased from Qing Dao Hai Yang Chemical Industry Co. of China. ${ }^{1} \mathrm{H},{ }^{13} \mathrm{C}$, and ${ }^{31} \mathrm{P}$ NMR spectra were recorded on a Bruker DPX-300 or AVANCE III400 Spectrometer. ${ }^{1} \mathrm{H}$ and ${ }^{13} \mathrm{C}$ NMR chemical shifts were reported in parts per million (ppm) relative to $\mathrm{Si}\left(\mathrm{CH}_{3}\right)_{4}$ as external standard. ${ }^{31} \mathrm{P}$ NMR downfield chemical shifts were expressed with a positive sign, in ppm, relative to external $85 \% \mathrm{H}_{3} \mathrm{PO}_{4}$. Highresolution mass spectra were obtained on a Varian MAT 311, Waters Q-TOF 2 or ZabSpec TOF Micromass instrument at CRMPO, University of Rennes 1. Elemental analyses were performed by the CRMPO, University of Rennes 1 .

Determination of optical data: UV/Vis spectra were recorded at room temperature on a Varian Cary 5000 UV-Vis-NIR spectrophotometer. Luminescence spectra were recorded at room temperature with a FS920 Steady State Fluorimeter (M300, UC920, CD920/CD930, S900) using a xenon lamp (Xe900). All spectra were recorded in $\mathrm{CH}_{2} \mathrm{Cl}_{2}$ (SDS, HPLC grade) stabilized with ethanol, with concentrations of $5.10^{-6}, 10^{-5}$, $5.10^{-5}$ and $10^{-4} \mathrm{M}$. Quantum yields were calculated relative to quinine sulfate $(\phi=0.546$ in $\left.\mathrm{H}_{2} \mathrm{SO}_{4} 0.1 \mathrm{~N}\right)^{[10]}$, using the following equation $Q_{x} / Q_{r}=\left[A_{r}(\lambda) / A_{x}\left(\lambda^{\prime}\right)\right]\left[n_{x}{ }^{2} / n_{r}{ }^{2}\right]\left[D_{x}\right.$ $\left./ D_{r}\right]$ where $\mathrm{A}$ is the absorbance at the excitation wavelength $(\lambda), \mathrm{n}$ the refractive index and $\mathrm{D}$ the integrated luminescence intensity. " $\mathrm{r}$ " and " $\mathrm{x}$ " stand for reference and sample. Excitations of references and samples compounds were performed at the maximum wavelength of the molecules.

Cyclic voltammetry measurements: The electrochemical studies were carried out under argon using an Eco Chemie Autolab PGSTAT 30 potentiostat for cyclic voltammetry with the three-electrode configuration: the working electrode was a platinum disk, the reference electrode a saturated calomel electrode and the counter-electrode a platinum wire. All potential were internally referenced to the ferrocene/ferrocenium couple. For the measurements concentrations of $10^{-3} \mathrm{M}$ of the electroactive species were used in freshly distilled and degassed dichloromethane (Lichrosolv, Merck) and $0.2 \mathrm{M}$ tetrabutylammonium hexafluorophosphate (TBAHFP, Fluka) which was twice recrystallized from ethanol and dried under vacuum prior to use.

Device fabrication and characterization: EL devices, based on a multilayer structure have been fabricated onto patterned ITO coated glass substrates from XinYan Technology (thickness: $100 \mathrm{~nm}$ and sheet resistance: less of $20 \Omega / \mathrm{m}$ ). The organic materials (from Aldrich and Lumtec) are deposited onto the ITO anode by sublimation under high vacuum $\left(<10^{-6}\right.$ Torr $)$ at a rate of $0.2-0.3 \mathrm{~nm} / \mathrm{s}$. The common structure of all the devices is the following: a thin layer (10 nm thick) of copper phtalocyanine $(\mathrm{CuPc})$ is used as hole injection layer (HIL) and $50 \mathrm{~nm}$ of N,N'-diphenyl-N,N'-bis(1naphthylphenyl)-1,1'-biphenyl-4,4'-diamine ( $\alpha$-NPB) as hole transporting layer (HTL). The emitting layer consists of $15 \mathrm{~nm}$ thick film of pure phosphole derivatives or DPVBi (or CBP) doped phosphole derivatives. The doped layer is obtained by co-evaporation of the two compounds and the doping rate is controlled by tuning the evaporation rate of each material. A thin layer of bathocuproine (BCP) $(10 \mathrm{~nm})$ is used as hole blocking layer. $\mathrm{Alq}_{3}(10 \mathrm{~nm})$ is used as electron transporting layer (ETL). Finally, a cathode consisting of $1.2 \mathrm{~nm}$ of $\mathrm{LiF}$ capped with $100 \mathrm{~nm}$ of $\mathrm{Al}$ is deposited onto the organic stack. The entire device is fabricated in the same run without breaking the vacuum. In this study, the thicknesses of the different organic layers were kept constant for all the 
devices. The active area of the devices defined by the overlap of the ITO anode and the metallic cathode was $0.28 \mathrm{~cm}^{2}$.

The current-voltage-luminance (I-V-L) characteristics of the devices were measured with a regulated power supply (Laboratory Power Supply EA-PS 3032-10B) combined with a multimeter and a $1 \mathrm{~cm}^{2}$ area silicon calibrated photodiode (Hamamatsu). The spectral emission was recorded with a SpectraScan PR655 spectrophotometer. All the measurements were performed at room temperature and at ambient atmosphere with no further encapsulation of devices immediately after the device realization.

Details of the X-ray crystallography study: single crystal data collection were performed at $100 \mathrm{~K}$ with an APEX II Bruker-AXS (Centre de Diffractométrie, Université de Rennes 1 , France) with Mo-K $\alpha$ radiation $(\lambda=0.71073 \AA$ ). Reflections were indexed, Lorentz-polarization corrected and integrated by the DENZO program of the KappaCCD software package. The data merging process was performed using the SCALEPACK program. ${ }^{[11]}$ Structure determinations were performed by direct methods with the solving program SIR97 ${ }^{[12]}$ that revealed all the non hydrogen atoms. SHELXL program (G.M. Sheldrick SHELX97, Program for the Refinement of Crystal Structures, University of Göttingen, Germany, 1997) was used to refine the structures by fullmatrix least-squares based on $F^{2}$. All non-hydrogen atoms were refined with anisotropic displacement parameters. Hydrogen atoms were included in idealized positions and refined with isotropic displacement parameters. Atomic scattering factors for all atoms were taken from International Tables for X-ray Crystallography. ${ }^{[13]}$ Details of crystal data and structural refinements are given in Table S2.

Crystallographic data. CCDC-948792 reference number contains the supplementary crystallographic data for 5a respectively. These data can be obtained free of charge at www.ccdc.cam.ac.uk/conts/retreving.html or from the Cambridge Crystallographic Data Center, 12 union Road, Cambridge CB2 1EZ, UK; Fax: (internat.) + 44-1223-336-033; E-mail: deposit@ccdc.cam.ac.uk].

Calculations on the phosphete derivatives: All the density functional calculations were carried out using the Gaussian 03 code. This level of the theory has provided satisfactory results for the phosphete oligomers. ${ }^{[14]}$ The geometries were fully optimized, and vibrational analysis was performed on the optimized structures to check whether the stationary point located is a minimum of the potential energy hypersurface. The density functional theory (DFT) calculation and structure optimization of 2a, 3a-c were conducted at the B3LYP/6-31+G (d, p) level.

Experimental part

\section{a) Synthesis of $\mathbf{I a}-f$}

Phenylbis(2-phenylethynyl)phosphine (1a) was prepared according to the previously reported procedure ${ }^{[15]}$. A similar procedure was used to prepare $\mathbf{1 b}-\mathbf{f}$. The typical procedure is as follows: a mixture of terminal alkyne $(12.8 \mathrm{mmol}), \mathrm{PhPCl}_{2}(0.7$ $\mathrm{mL}, 5.2 \mathrm{mmol}), \mathrm{CuI}\left(0.1 \mathrm{~g}, 0.52 \mathrm{mmol}, \mathrm{NEt}_{3}(4.35 \mathrm{~mL})\right.$ and toluene $(35 \mathrm{~mL})$ was stirred at room temperature for $12 \mathrm{~h}$. After filtration and removal of the solvent, the residue was chromatographed over silica gel (hexane) to give $\mathbf{1}$.

Synthesis of $\mathbf{I b}$ : The compound $\mathbf{1 b}$ is obtained as yellow solid $(1.60 \mathrm{~g}, 4.3 \mathrm{mmol}$, Yield: $83 \%){ }^{31} \mathrm{P}$ NMR $(\mathrm{CDCl} 3 ; 121 \mathrm{MHz}): \delta=-60.7(\mathrm{~s}) .{ }^{1} \mathrm{H} \mathrm{NMR}(\mathrm{CDCl} 3 ; 300 \mathrm{MHz}): \delta=$ $3.82\left(\mathrm{~s}, 6 \mathrm{H}, \mathrm{OCH}_{3}\right), 7.18$ ( $\mathrm{AB}$ system, $8 \mathrm{H}, J_{\mathrm{AB}}=8.9 \mathrm{~Hz}, \Delta v_{\mathrm{AB}}=188.3 \mathrm{~Hz}, \mathrm{CH}_{\text {phenyl-OCH3 }}$ ), 7.44-7.51 (m, 3H, CHphenyl), 7.87-7.93 (m, 2H, CHphenyl); ${ }^{13} \mathrm{C}$ NMR (CDCl3; 75 $\mathrm{MHz}): \delta=55.3\left(\mathrm{~s}, \mathrm{OCH}_{3}\right), 81.4(\mathrm{~s}, C \equiv \mathrm{C}), 106.5(\mathrm{~d}, J(\mathrm{C}, \mathrm{P})=7.4 \mathrm{~Hz}, C \equiv \mathrm{C}), 113.9(\mathrm{~s}$ CHphenyl), 114.6 (s, Cphenyl), 128.8 (d, J(C,P) = 7.6 Hz, CHphenyl), 129.3 (s, CHphenyl), $132.0(\mathrm{~d}, J(\mathrm{C}, \mathrm{P})=21.8 \mathrm{~Hz}, C$ Hphenyl), $133.7(\mathrm{~d}, J(\mathrm{C}, \mathrm{P})=1.5 \mathrm{~Hz}$, CHphenyl), 133.8 (s, Cphenyl), 160.3 (s, Cphenyl). MS (ESI, MeOH, $m / z$ ): $[\mathrm{M}+\mathrm{K}]^{+}$ calcd for $\mathrm{C}_{24} \mathrm{H}_{19} \mathrm{O}_{2} \mathrm{KP}, 409.07$; found 409.1

Synthesis of 1c: The compound 1c is obtained as brown solid $(1.09 \mathrm{~g}, 2.4 \mathrm{mmol}$, Yield: $47 \%) ;{ }^{31} \mathrm{P}$ NMR $(\mathrm{CDCl} 3 ; 121 \mathrm{MHz}): \delta=-61.6(\mathrm{~s}) .{ }^{1} \mathrm{H} \mathrm{NMR}(\mathrm{CDCl} 3 ; 300 \mathrm{MHz}): \delta=$ 7.47-7.50 (m, 3H, CHphenyl), 7.59-7.65 (m, 8H, CHphenyl), 7.86-7.92 (m, 2H,
CHphenyl); ${ }^{13} \mathrm{C}$ NMR $(\mathrm{CDCl} 3 ; 75 \mathrm{MHz}): \delta=85.5(\mathrm{~d}, J(\mathrm{C}, \mathrm{P})=6.3 \mathrm{~Hz}, C \equiv \mathrm{C}), 104.8(\mathrm{~d}$, $J(\mathrm{C}, \mathrm{P})=6.4 \mathrm{~Hz}, C \equiv \mathrm{C}), 123.8\left(\mathrm{q}, J(\mathrm{C}, \mathrm{F})=270.6 \mathrm{~Hz}, C \mathrm{~F}_{3}\right), 125.3(\mathrm{q}, J(\mathrm{C}, \mathrm{F})=3.7 \mathrm{~Hz}$, CHphenyl), 126.0 (s, Cphenyl), 129.1 (d, J(C,P) = 8.2 Hz, CHphenyl), 130.1 (s, CHphenyl), 130.8 (q, $J(\mathrm{C}, \mathrm{F})=32.6 \mathrm{~Hz}, C$ phenyl), 132.0 (s, Cphenyl), 132.17 (d, J(C,P) $=1.6 \mathrm{~Hz}, C$ Hphenyl), $132.5(\mathrm{~d}, J(\mathrm{C}, \mathrm{P})=22.4 \mathrm{~Hz}, C$ Hphenyl $)$. MS $(\mathrm{ESI}, \mathrm{MeOH}, m / z)$ : $[\mathrm{M}+\mathrm{K}]^{+}$calcd for $\mathrm{C}_{24} \mathrm{H}_{13} \mathrm{~F}_{6} \mathrm{KP}, 485.03$; found 485.0.

Synthesis of $\mathbf{1 d}$ : The compound $\mathbf{1 c}$ is obtained as white solid $(1.38 \mathrm{~g}, 2.5 \mathrm{mmol}$, Yield: $49 \%) ;{ }^{31} \mathrm{P}$ NMR $(\mathrm{CDCl} 3 ; 121 \mathrm{MHz}): \delta=-60.7$ (s). ${ }^{1} \mathrm{H}$ NMR $(\mathrm{CDCl} 3 ; 300 \mathrm{MHz}): \delta$ $=1.65\left(\mathrm{~s}, 12 \mathrm{H} ; \mathrm{CH}_{3}\right), 7.50-7.90(\mathrm{~m}, 17 \mathrm{H}, \mathrm{CHphenyl}), 8.32(\mathrm{t}, 2 \mathrm{H}, J(\mathrm{H}, \mathrm{H})=8.4 \mathrm{~Hz}$, $J(\mathrm{H}, \mathrm{P})=8.4 \mathrm{~Hz}, \mathrm{CH}$ phenyl). ${ }^{13} \mathrm{C} \mathrm{NMR}(\mathrm{CDCl} 3 ; 75 \mathrm{MHz}): \delta=27.2\left(\mathrm{~s}, \mathrm{CH}_{3}\right), 47.1(\mathrm{~s}$, $\left.C\left(\mathrm{CH}_{3}\right)_{2}\right), 83.3$ (s, $\left.C \equiv \mathrm{C}\right), 107.8(\mathrm{~d}, J(\mathrm{C}, \mathrm{P})=7.4 \mathrm{~Hz}, C \equiv \mathrm{C}), 120.3$ (s, $C$ Hphenyl), 120.8 (s, CHphenyl), 121.1 (s, Cphenyl), 123.0 (s, CHphenyl), 126.7 (s, CHphenyl), 127.5 (s, CHphenyl), 128.3 (s, CHphenyl), 129.3 (d, J(C,P) = $7.8 \mathrm{~Hz}, C$ Hphenyl), 129.9 (s, CHphenyl), 131.7 (s, CHphenyl), 132.6 (d, J(C,P) = $21.8 \mathrm{~Hz}, C$ Hphenyl), 133.8 (s, Cphenyl), 138.5 (s, Cphenyl), 140.6 (s, Cphenyl), 153.8 (s, Cphenyl), 154.2 (s, $C$ phenyl). MS (ESI, MeOH, $m / z$ ): $[\mathrm{M}+\mathrm{H}]^{+}$calcd for $\mathrm{C}_{40} \mathrm{H}_{32} \mathrm{P}, 543.2$; found 543.2.

Synthesis of $1 \boldsymbol{e}$ : The compound 1e is obtained as white solid $(1.77 \mathrm{~g}, 4.3 \mathrm{mmol}$, Yield: $83 \%) .{ }^{31} \mathrm{P}$ NMR $(\mathrm{CDCl} 3 ; 121 \mathrm{MHz}): \delta=-60.8(\mathrm{~s}) .{ }^{1} \mathrm{H} \mathrm{NMR}(\mathrm{CDCl} 3 ; 300 \mathrm{MHz}): \delta=$ 7.49-7.68 (m, 9H, CHaromatic), 7.89-7.94 (m, 6H, CHaromatic), $8.22(\mathrm{t}, 2 \mathrm{H}, J(\mathrm{H}, \mathrm{H})=$ $8.4 \mathrm{~Hz}, J(\mathrm{H}, \mathrm{P})=9.0 \mathrm{~Hz}, \mathrm{CH}$ aromatic $), 8.56(\mathrm{~d}, 2 \mathrm{H}, J(\mathrm{H}, \mathrm{H})=8.1 \mathrm{~Hz}, \mathrm{CH}$ aromatic $) .{ }^{13} \mathrm{C}$ $\mathrm{NMR}(\mathrm{CDCl} 3 ; 75 \mathrm{MHz}): \delta=88.3(\mathrm{~d}, J(\mathrm{C}, \mathrm{P})=4.5 \mathrm{~Hz}, C \equiv \mathrm{C}), 104.8(\mathrm{~d}, J(\mathrm{C}, \mathrm{P})=6.8 \mathrm{~Hz}$, $C \equiv \mathrm{C}$ ), 120.2 (s, Caromatic), 125.3 (s, CHaromatic), 126.2 (s, CHaromatic), 126.7 (s, CHaromatic), 127.3 (s, CHaromatic), 128.5 (s, CHaromatic), 129.2 (d, $J(\mathrm{C}, \mathrm{P})=8.0 \mathrm{~Hz}$, CHaromatic), 129.9 (s, CHaromatic), 131.3 (d, J(C,P) = 1.7 Hz, CHaromatic), 132.4 (s, CHaromatic), 132.7 (s, CHaromatic), 133.2 (s, Caromatic), 133.5 (s Caromatic), 133.6 (s Caromatic). MS (ESI, MeOH, $m / z)$ : $[\mathrm{M}+\mathrm{H}]^{+}$calcd for $\mathrm{C}_{30} \mathrm{H}_{20} \mathrm{P}, 411.5$; found 411.3.

Synthesis of $\mathbf{I}$ : The compound $\mathbf{1 f}$ is obtained as white solid (2.02 g, $3.2 \mathrm{mmol}$, Yield: $62 \%) ;{ }^{31} \mathrm{P}$ NMR $(\mathrm{CDCl} 3 ; 121 \mathrm{MHz}): \delta=-61.4(\mathrm{~s}) .{ }^{1} \mathrm{H}$ NMR $(\mathrm{CDCl} 3 ; 300 \mathrm{MHz}): \delta=$ $0.90\left(\mathrm{t}, 6 \mathrm{H}, J(\mathrm{H}, \mathrm{H})=6.9 \mathrm{~Hz}, \mathrm{CH}_{3}\right), 1.35-1.38\left(\mathrm{~m}, 8 \mathrm{H}, \mathrm{CH}_{2}\right), 1.85-1.89\left(\mathrm{~m}, 4 \mathrm{H}, \mathrm{CH}_{2}\right)$, $4.28\left(\mathrm{t}, 4 \mathrm{H}, J(\mathrm{H}, \mathrm{H})=7.2 \mathrm{~Hz}, \mathrm{~N}-\mathrm{CH}_{2}\right), 7.26-7.55(\mathrm{~m}, 11 \mathrm{H}, \mathrm{CHphenyl}), 7.67(\mathrm{dd}, 2 \mathrm{H}$, $J(\mathrm{H}, \mathrm{H})=1.2 \mathrm{~Hz}, J(\mathrm{H}, \mathrm{H})=8.4 \mathrm{~Hz}, \mathrm{CHphenyl}), 8.03-8.05(\mathrm{~m}, 2 \mathrm{H}, \mathrm{CH}$ phenyl), 8.09 (d, $2 \mathrm{H}, J(\mathrm{H}, \mathrm{H})=7.8 \mathrm{~Hz} \mathrm{CH}$ phenyl), 8.34 (s, 2H, CHphenyl). ${ }^{13} \mathrm{C} \mathrm{NMR}(\mathrm{CDCl} 3 ; 75 \mathrm{MHz})$ : $\delta=14.1\left(\mathrm{~s}, \mathrm{CH}_{3}\right), 22.6\left(\mathrm{~s}, \mathrm{CH}_{2}\right), 28.8\left(\mathrm{~s}, \mathrm{CH}_{2}\right), 29.4\left(\mathrm{~s}, \mathrm{CH}_{2}\right), 43.2\left(\mathrm{~s}, \mathrm{CH}_{2}\right), 80.9$ (s, $C \equiv \mathrm{C}), 108.3(\mathrm{~d}, J(\mathrm{C}, \mathrm{P})=7.7 \mathrm{~Hz}, C \equiv \mathrm{C}), 108.8$ (s, CHphenyl), 109.1 (s, CHphenyl), 112.5 (s $C$ phenyl), 119.6 (s, CHphenyl), 120.6 (s, CHphenyl), 122.5 (s, Cphenyl), 122.8 (s, Cphenyl), 124.9 (s, CHphenyl), 126.3 (s, CHphenyl), 128.9 (d, $J(\mathrm{C}, \mathrm{P})=7.5 \mathrm{~Hz}$, CHphenyl), 129.3 (s, CHphenyl), 129.8 (s, CHphenyl), 132.2 (d, $J(\mathrm{C}, \mathrm{P})=21.2 \mathrm{~Hz}$, CHphenyl), 134.6 (s, Cphenyl), 140.6 (s Cphenyl), 140.8 (s Cphenyl). MS (ESI, MeOH, $\mathrm{m} / \mathrm{z}$ ): $[\mathrm{M}+\mathrm{H}]^{+}$calcd for $\mathrm{C}_{44} \mathrm{H}_{42} \mathrm{~N}_{2} \mathrm{P}, 629.8$; found 629.6.

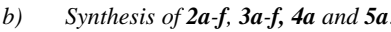

Synthesis of $3 \boldsymbol{a}$ : Bromobenzene ( $312 \mu \mathrm{L}, 3.0 \mathrm{mmol})$ was added to a distilled ether solution $(20 \mathrm{~mL})$ containing an excess of $\mathrm{Mg}(86 \mathrm{mg}, 3.6 \mathrm{mmol})$ at room temperature. After $1 \mathrm{~h}$ of stirring at $40{ }^{\circ} \mathrm{C}, \mathrm{Cp}_{2} \mathrm{ZrCl}_{2}(292 \mathrm{mg}, 1.0 \mathrm{mmol})$ was introduced in the solution. The solution was stirred until complete dissolution of the solid, then dioxane ( $258 \mu \mathrm{L}, 3.0 \mathrm{mmol}$ ) was added generating a white precipitate. The mixture was stirred for $1 \mathrm{~h}$ at room temperature and the solvent was evaporated under vacuum. The white solid was dissolved in $20 \mathrm{~mL}$ of degassed toluene and Phenylbis(2phenylethynyl)phosphine 1a (293 mg, $0.95 \mathrm{mmol})$ was added. After $20 \mathrm{~h}$ of stirring at $80^{\circ} \mathrm{C}$, a solution of $20 \mathrm{~mL}$ toluene charged with $\mathrm{HCl}$ gas (from $\mathrm{NH}_{4} \mathrm{Cl}+\mathrm{H}_{2} \mathrm{SO}_{4}$ ) was added to the mixture at $0{ }^{\circ} \mathrm{C}$. After $1 \mathrm{~h}$ of stirring at room temperature, the solution was filtered and the solvent was removed under vacuum. The crude residue was dissolved in $10 \mathrm{~mL} \mathrm{CH}_{2} \mathrm{Cl}_{2}$ and an excess of $\mathrm{H} 2 \mathrm{O} 2(5 \mathrm{~mL})$ was added. After $1 \mathrm{~h}$ of stirring at room temperature, water was added $(10 \mathrm{~mL})$ to the reaction mixture and the aqueous layer was extracted with $\mathrm{CH}_{2} \mathrm{Cl}_{2}(3 \times 5 \mathrm{~mL})$. The organic layer was dried over anhydrous $\mathrm{MgSO}_{4}$ and the solvent was evaporated under vacuum. The crude product was purified by chromatography on silica (Petroleum ether/AcOEt, 2/1, v/v). The recovered fraction 
was crystallized in $\mathrm{Et}_{2} \mathrm{O}$ to get a pure white solid in a $56 \%$ yield ( $215 \mathrm{mg}, 0.53 \mathrm{mmol}$ ) ${ }^{31} \mathrm{P}$ NMR (CDCl3; $\left.121 \mathrm{MHz}\right): \delta=+35.6$ (s). ${ }^{1} \mathrm{H}$ NMR $(\mathrm{CDCl} 3 ; 300 \mathrm{MHz}): \delta=7.23-$ $7.63(\mathrm{~m}, 18 \mathrm{H}, \mathrm{CHphenyl}), 7.89(\mathrm{~d}, 1 \mathrm{H}, J(\mathrm{H}, \mathrm{P})=70.5 \mathrm{~Hz},=\mathrm{CH}), 7.87(\mathrm{dd}, 2 \mathrm{H}, J(\mathrm{H}, \mathrm{P})=$ $12.0 \mathrm{~Hz}, J(\mathrm{H}, \mathrm{H})=7.5 \mathrm{~Hz}, \mathrm{C} H$ phenyl). ${ }^{13} \mathrm{C}$ NMR $(\mathrm{CDCl} 3 ; 75 \mathrm{MHz}): \delta=127.2(\mathrm{~d}$, $J(\mathrm{C}, \mathrm{P})=8.9 \mathrm{~Hz}, C$ Hphenyl), 128.3 (s, CHphenyl), 128.4 (s, CHphenyl), 128.5 (s, CHphenyl), 128.6 (s, CHphenyl), 128.9 (s, CHphenyl), 129.0 (d, J(C,P) $=11.9 \mathrm{~Hz}$ CHphenyl), 129.1 (s, CHphenyl), 129.8 (s, CHphenyl), 129.9 (s, CHphenyl), 130.7 (d, $J(\mathrm{C}, \mathrm{P})=85.1 \mathrm{~Hz}, C \mathrm{ipso}), 131.0(\mathrm{~d}, J(\mathrm{C}, \mathrm{P})=5.8 \mathrm{~Hz}, C$ phenyl), $131.2(\mathrm{~d}, J(\mathrm{C}, \mathrm{P})=11.3$ $\mathrm{Hz}, C$ Hphenyl), $132.5(\mathrm{~d}, J(\mathrm{C}, \mathrm{P})=2.7 \mathrm{~Hz}, C$ Hphenyl $), 139.3(\mathrm{~d}, J(\mathrm{C}, \mathrm{P})=8.8 \mathrm{~Hz}$, Cphenyl), 139.4 (d $J(\mathrm{C}, \mathrm{P})=16.9 \mathrm{~Hz}, C \mathrm{sp} 2), 140.0$ (s, Cphenyl), $142.1(\mathrm{~d}, J(\mathrm{C}, \mathrm{P})=77.0$ $\mathrm{Hz}, C \mathrm{sp} 2), 144.7(\mathrm{~d}, J(\mathrm{C}, \mathrm{P})=12.5 \mathrm{~Hz},=C \mathrm{H}), 155.7(\mathrm{~d}, J(\mathrm{C}, \mathrm{P})=78.4 \mathrm{~Hz}, C \mathrm{sp} 2) . \mathrm{HR}$ MS (ESI, $\mathrm{CHCl}_{3} / \mathrm{MeOH}, 50 / 50, \mathrm{v} / \mathrm{v}, \mathrm{m} / z$ ): $[\mathrm{M}+\mathrm{Na}]^{+}$calcd for $\mathrm{C}_{28} \mathrm{H}_{21} \mathrm{ONaP}$, 427.12277; found 427.1228; Anal. Calcd for $\mathrm{C}_{28} \mathrm{H}_{21} \mathrm{OP}$ (404.45): C 83.15, H 5.23, found: C 82.37, H 5.24 .

Synthesis of $4 \mathbf{a}$ : The procedure is similar as for $\mathbf{3 a}$. Instead of adding $\mathrm{H}_{2} \mathrm{O}_{2}, \mathrm{~S}_{8}(38 \mathrm{mg}$, $1.2 \mathrm{mmol}$ ) was added. The mixture was stirred for $12 \mathrm{~h}$ at $50{ }^{\circ} \mathrm{C}$. The crude residue was purified by column chromatography on silica with Petroleum ether/ $\mathrm{CH}_{2} \mathrm{Cl}_{2}(1 / 1)$ as eluent. The product was obtained as a pale yellow solid in a 54\% yield (215 mg, 0.51 mmol) ${ }^{31}{ }^{1} \mathrm{P} \mathrm{NMR}(\mathrm{CDCl} 3 ; 121 \mathrm{MHz}): \delta=+57.3(\mathrm{~s}) .{ }^{1} \mathrm{H}$ NMR $(\mathrm{CDCl} 3,300 \mathrm{MHz}): \delta=$ 7.03-7.43 (m, 18H, CHphenyl), $7.69(\mathrm{~d}, 1 \mathrm{H}, J(\mathrm{H}, \mathrm{P})=69.9 \mathrm{~Hz},=\mathrm{CH}), 7.94(\mathrm{ddd}, 2 \mathrm{H}$, $J(\mathrm{H}, \mathrm{P})=14.1 \mathrm{~Hz}, J(\mathrm{H}, \mathrm{H})=7.8 \mathrm{~Hz}, J(\mathrm{H}, \mathrm{H})=1.5 \mathrm{~Hz}, \mathrm{C}$ phenyl). ${ }^{13} \mathrm{C}$ NMR $(\mathrm{CDCl} 3 ; 75$ MHz): $\delta=126.8(\mathrm{~d}, J(\mathrm{C}, \mathrm{P})=9.2 \mathrm{~Hz}, C$ Hphenyl), 128.1 (s, CHphenyl), $128.4(\mathrm{~s}$ CHphenyl), 128.5 (s, CHphenyl), 128.6 (s, CHphenyl), 128.9 (s, CHphenyl), 129.0 (s, CHphenyl), 129.6 (s, CHphenyl), 129.9 (s, CHphenyl), 130.1 (s, CHphenyl), 130.7 (d, $J(\mathrm{C}, \mathrm{P})=6.2 \mathrm{~Hz}, C$ phenyl), $130.8(\mathrm{~d}, J(\mathrm{C}, \mathrm{P})=64.8 \mathrm{~Hz}, \mathrm{Cipso}), 131.4(\mathrm{~d}, J(\mathrm{C}, \mathrm{P})=12.2$ Hz, CHphenyl), $132.4(\mathrm{~d}, J(\mathrm{C}, \mathrm{P})=3.0 \mathrm{~Hz}, C$ Hphenyl) $138.6(\mathrm{~d}, J(\mathrm{C}, \mathrm{P})=8.3 \mathrm{~Hz}$, Cphenyl), 139.2 (d $J(\mathrm{C}, \mathrm{P})=16.7 \mathrm{~Hz}, C \mathrm{sp} 2), 139.3$ (s, Cphenyl), $140.2(\mathrm{~d}, J(\mathrm{C}, \mathrm{P})=67.2$ $\mathrm{Hz}, C \mathrm{sp} 2), 143.6(\mathrm{~d}, J(\mathrm{C}, \mathrm{P})=12.2 \mathrm{~Hz},=C \mathrm{H}), 153.1(\mathrm{~d}, J(\mathrm{C}, \mathrm{P})=68.6 \mathrm{~Hz}, C \mathrm{sp} 2) . \mathrm{HR}-$ MS (ESI, $\mathrm{CHCl}_{3} / \mathrm{MeOH}, 50 / 50, \mathrm{v} / \mathrm{v}, \mathrm{m} / z$ ): $[\mathrm{M}+\mathrm{Na}]^{+}$calcd for $\mathrm{C}_{28} \mathrm{H}_{21} \mathrm{SNaP}, 443.09993$; found 443.0999; Anal. Calcd for $\mathrm{C}_{28} \mathrm{H}_{21} \mathrm{PS}$ (420.51): C 79.98, H 5.03, S 7.63, found: C 80.01, H 5.00, S 7.66 .

Synthesis of 5a: The procedure is similar as for 3a. Instead of adding $\mathrm{H}_{2} \mathrm{O}_{2}$, (tht)AuC (256 mg, $0.8 \mathrm{mmol}$ ) was added and stirred for $1 \mathrm{~h}$. After solvent evaporation, crude residue was purified by column chromatography on silica with Petroleum ether/ $\mathrm{CH}_{2} \mathrm{Cl}_{2}$ (2/1) as eluent. Possible further purification via crystallization in $\mathrm{CH}_{2} \mathrm{Cl}_{2} /$ hexane. The product was obtained as pale yellow crystals in a $34 \%$ yield $(203 \mathrm{mg}, 0.32 \mathrm{mmol}) .{ }^{31} \mathrm{P}$ NMR $(\mathrm{CDCl} 3 ; 121 \mathrm{MHz}): \delta=+49.6(\mathrm{~s}) .{ }^{1} \mathrm{H}$ NMR $(\mathrm{CDCl} 3 ; 300 \mathrm{MHz}): \delta=7.07-7.42$ $(\mathrm{m}, 18 \mathrm{H}, \mathrm{CH}$ phenyl), $7.61(\mathrm{ddd}, 2 \mathrm{H}, J(\mathrm{H}, \mathrm{P})=14.1 \mathrm{~Hz}, J(\mathrm{H}, \mathrm{H})=8.7 \mathrm{~Hz}, J(\mathrm{H}, \mathrm{H})=1.5$ $\mathrm{Hz}, \mathrm{CH}$ phenyl), $7.67(\mathrm{~d}, 1 \mathrm{H}, J(\mathrm{H}, \mathrm{P})=51.6 \mathrm{~Hz},=C H) .{ }^{13} \mathrm{C} \mathrm{NMR}(\mathrm{CDCl} 3 ; 75 \mathrm{MHz}): \delta=$ $126.3(\mathrm{~d}, J(\mathrm{C}, \mathrm{P})=8.9 \mathrm{~Hz}, C$ Hphenyl), $127.7(\mathrm{~d}, J(\mathrm{C}, \mathrm{P})=43.9 \mathrm{~Hz}, C$ ipso $), 128.4(\mathrm{~s}$, CHphenyl), 128.9 (s, CHphenyl), 129.0 (d, J(C,P) = $12.8 \mathrm{~Hz}, C$ Hphenyl), 129.2 (s, CHphenyl), 129.4 (d, J(C,P) = $11.9 \mathrm{~Hz}, C$ Hphenyl), 129.6 (s, CHphenyl), 129.8 (s, CHphenyl), 130.3 (s, CHphenyl), 130.8 (d, J(C,P) = 7.3 Hz, Cphenyl), 130.9 (d, J(C,P) = $57.4 \mathrm{~Hz}, C$ ipso), 133.3 (s, CHphenyl), $133.4(\mathrm{~d}, J(\mathrm{C}, \mathrm{P})=14.3 \mathrm{~Hz}, C$ Hphenyl), 138.3 $\left(\mathrm{d}, J(\mathrm{C}, \mathrm{P})=14.1 \mathrm{~Hz}, C_{\mathrm{sp} 2}\right), 138.4(\mathrm{~d}, J(\mathrm{C}, \mathrm{P})=7.5 \mathrm{~Hz}, C$ phenyl $), 141.4(\mathrm{~s}, C$ phenyl $)$, $143.0(\mathrm{~d}, J(\mathrm{C}, \mathrm{P})=7.2 \mathrm{~Hz},=C \mathrm{H}), 147.5(\mathrm{~d}, J(\mathrm{C}, \mathrm{P})=52.1 \mathrm{~Hz}, C$ sp2). HR-MS (ESI, $\mathrm{CH}_{3} \mathrm{OCH}_{3}, \mathrm{~m} / \mathrm{z}$ ): $[\mathrm{M}+\mathrm{Na}]^{+}$calcd for $\mathrm{C}_{28} \mathrm{H}_{21} \mathrm{ClAuNaP}, 643.06327$; found 643.0632; Anal. Calcd for $\mathrm{C}_{28} \mathrm{H}_{21} \mathrm{AuClP}$ (620.87): C 54.17, H 3.41, found: C 54.49, H 3.28 .

Synthesis of $\mathbf{3 b}$ : The procedure is similar as for $\mathbf{3 a}$. The crude residue was purified by column chromatography on silica (petroleum ether/AcOEt, 1/1) and recrystallization in absolute ethanol permit to afford product in a $45 \%$ yield $(200 \mathrm{mg}, 0.43 \mathrm{mmol}) .{ }^{31} \mathrm{P}$ NMR (CDCl3; $121 \mathrm{MHz}): \delta=34.4$ (s). ${ }^{1} \mathrm{H} \mathrm{NMR}(\mathrm{CDCl} 3,300 \mathrm{MHz}): \delta=3.69(\mathrm{~s}, 3 \mathrm{H}$, OCH3), 3.70 (s, 3H, OCH3), $6.73(\mathrm{~d}, 2 \mathrm{H}, J(\mathrm{H}, \mathrm{H})=8.7 \mathrm{~Hz}, \mathrm{CH}$ phenyl), 6.79 (d, 2H, $J(\mathrm{H}, \mathrm{H})=8.4 \mathrm{~Hz}, \mathrm{CH}$ phenyl), 7.30-7.43 (m, 12H, CHphenyl), $7.70(\mathrm{~d}, 1 \mathrm{H}, J(\mathrm{H}, \mathrm{P})=71.4$ $\mathrm{Hz},=C H), 7.88\left(\mathrm{dd}, 2 \mathrm{H}, J(\mathrm{H}, \mathrm{P})=11.4 \mathrm{~Hz}, J(\mathrm{H}, \mathrm{H})=7.5 \mathrm{~Hz}, \mathrm{C} H\right.$ phenyl). ${ }^{13} \mathrm{C}$ NMR $(\mathrm{CDCl} 3,75 \mathrm{MHz}): \delta=55.2(\mathrm{~s}, \mathrm{OCH} 3), 55.3(\mathrm{~s}, \mathrm{OCH} 3), 113.8$ (s, CHphenyl), 114.5 (s, CHphenyl), $123.9(\mathrm{~d}, J(\mathrm{C}, \mathrm{P})=6.0 \mathrm{~Hz}, C$ phenyl), 128.1 (s, CHphenyl), 128.5 (s,
CHphenyl), 128.7 (d, J(C,P) = 9.0 Hz, CHphenyl), $129.0(\mathrm{~d}, J(\mathrm{C}, \mathrm{P})=12 \mathrm{~Hz}, C$ Hphenyl), 129.9 (s, CHphenyl), 130.2 (s, CHphenyl), 130.8 (d, J(C,P) = 86.3 Hz, Cipso), 131.2 (d, $J(\mathrm{C}, \mathrm{P})=11.3 \mathrm{~Hz}, C$ Hphenyl $), 132.0(\mathrm{~d}, J(\mathrm{C}, \mathrm{P})=9.0 \mathrm{~Hz}, C$ phenyl $), 132.4(\mathrm{~d}, J(\mathrm{C}, \mathrm{P})=$ $3.0 \mathrm{~Hz}, C$ Hphenyl), 138.4 (d, $J(\mathrm{C}, \mathrm{P})=1.5 \mathrm{~Hz}, C$ phenyl), 139.7 (d, $J(\mathrm{C}, \mathrm{P})=17.3 \mathrm{~Hz}$, $C$ sp2), $140.2(\mathrm{~d}, J(\mathrm{C}, \mathrm{P})=77.3 \mathrm{~Hz}, C \mathrm{sp} 2), 142.3(\mathrm{~d}, J(\mathrm{C}, \mathrm{P})=12.0 \mathrm{~Hz},=C \mathrm{H}), 154.1(\mathrm{~d}$, $J(\mathrm{C}, \mathrm{P})=78.0 \mathrm{~Hz}, C \mathrm{sp} 2), 159.7$ (s, Cphenyl), 160.8 (s, Cphenyl). HR-MS (ESI, $\left.\mathrm{CHCl}_{3} / \mathrm{MeOH}, 50 / 50, \mathrm{v} / \mathrm{v}, \mathrm{m} / \mathrm{z}\right)$ : $[\mathrm{M}+\mathrm{Na}]^{+}$calcd for $\mathrm{C}_{30} \mathrm{H}_{25} \mathrm{O}_{3} \mathrm{NaP}, 487.1439$; found 487.1440; Anal. Calcd for $\mathrm{C}_{30} \mathrm{H}_{25} \mathrm{O}_{3} \mathrm{P}$ (464.49): C 77.57, H 5.43, found: C 77.50, H 5.30.

Synthesis of $\mathbf{3 c}$ : The procedure is similar as for $\mathbf{3 a}$. The crude residue was purified by column chromatography on silica with dichloromethane as eluent. Product was obtained as a yellow solid in a $35 \%$ yield $(180 \mathrm{mg}, 0.33 \mathrm{mmol}) .{ }^{31} \mathrm{P} \mathrm{NMR}(\mathrm{CDCl} 3 ; 121 \mathrm{MHz}): \delta$ $=+35.4(\mathrm{~s}) .{ }^{1} \mathrm{H}$ NMR $(\mathrm{CDCl} 3 ; 300 \mathrm{MHz}): \delta=7.20-7.23(\mathrm{~m}, 2 \mathrm{H}, \mathrm{CH}$ phenyl), 7.35-7.47 $(\mathrm{m}, 14 \mathrm{H}, \mathrm{CH}$ phenyl), $7.75(\mathrm{ddd}, 2 \mathrm{H}, J(\mathrm{H}, \mathrm{P})=12.6 \mathrm{~Hz}, J(\mathrm{H}, \mathrm{H})=6.9 \mathrm{~Hz}, J(\mathrm{H}, \mathrm{H})=1.8$ $\mathrm{Hz}, \mathrm{CH}$ phenyl). $7.90(\mathrm{~d}, 1 \mathrm{H}, J(\mathrm{H}, \mathrm{P})=69.0 \mathrm{~Hz},=C H) \cdot{ }^{13} \mathrm{C} \mathrm{NMR}(\mathrm{CDCl} 3,75 \mathrm{MHz}): \delta=$ $123.7(\mathrm{q}, J(\mathrm{C}, \mathrm{F})=270.5 \mathrm{~Hz}, C \mathrm{~F} 3), 123.9(\mathrm{q}, J(\mathrm{C}, \mathrm{F})=270.5 \mathrm{~Hz} C \mathrm{~F} 3), 125.4(\mathrm{q}, J(\mathrm{C}, \mathrm{F})=$ $3.5 \mathrm{~Hz}, C$ Hphenyl), 126.0 (q, $J(\mathrm{C}, \mathrm{F})=3.8 \mathrm{~Hz}, C$ Hphenyl), $127.4(\mathrm{~d}, J(\mathrm{C}, \mathrm{P})=8.6 \mathrm{~Hz}$, CHphenyl), 128.8 (s, CHphenyl), 128.9 (s, CHphenyl), 129.3 (d, $J(\mathrm{C}, \mathrm{P})=12.2 \mathrm{~Hz}$, CHphenyl), 129.4 (s, CHphenyl), 129.8 (s, CHphenyl), 130.3 (q, J(C,F) = 32.2 Hz, Cphenyl), $130.6(\mathrm{~d}, J(\mathrm{C}, \mathrm{P})=86.1 \mathrm{~Hz}, C$ ipso $), 131.2(\mathrm{~d}, J(\mathrm{C}, \mathrm{P})=11.4 \mathrm{~Hz}, C$ Hphenyl $)$, $131.4(\mathrm{q}, J(\mathrm{C}, \mathrm{F})=32.5 \mathrm{~Hz}, C$ phenyl $), 133.0(\mathrm{~d}, J(\mathrm{C}, \mathrm{P})=2.8 \mathrm{~Hz}, C$ Hphenyl $), 134.0(\mathrm{~d}$, $J(\mathrm{C}, \mathrm{P})=6.0 \mathrm{~Hz}, C$ phenyl $), 138.4(\mathrm{~d}, J(\mathrm{C}, \mathrm{P})=16.4 \mathrm{~Hz}, C \mathrm{sp} 2), 140.2(\mathrm{~s}, C$ phenyl $), 142.6$ $(\mathrm{d}, J(\mathrm{C}, \mathrm{P})=8.2 \mathrm{~Hz}, C$ phenyl $), 143.5(\mathrm{~d}, J(\mathrm{C}, \mathrm{P})=76.5 \mathrm{~Hz}, C \mathrm{sp} 2), 146.7(\mathrm{~d}, J(\mathrm{C}, \mathrm{P})=$ $11.8 \mathrm{~Hz},=C \mathrm{H}), 155.3(\mathrm{~d}, J(\mathrm{C}, \mathrm{P})=78.5 \mathrm{~Hz}, C \mathrm{sp} 2)$. HR-MS (ESI, $\mathrm{CHCl}_{3} / \mathrm{MeOH}, 50 / 50$, $\mathrm{v} / \mathrm{v}, \mathrm{m} / \mathrm{z}):[\mathrm{M}+\mathrm{Na}]^{+}$calcd for $\mathrm{C}_{30} \mathrm{H}_{19} \mathrm{OF}_{6} \mathrm{NaP}, 563.09754$; found 563.0977; Anal. Calcd for $\mathrm{C}_{30} \mathrm{H}_{19} \mathrm{OF}_{6} \mathrm{P}$ (540.446): C 66.67, H 3.54, found: C 66.81, H 3.40 .

Synthesis of $\mathbf{3 d}$ : The procedure is similar as for $\mathbf{3 a}$. The crude residue was purified by column chromatography on silica with Petroleum ether/AcOEt $(3 / 1, \mathrm{v} / \mathrm{v})$ as eluent. Product was obtained as a yellow solid ( $(278 \mathrm{mg}, 0.44 \mathrm{mmol}, 46 \%) .{ }^{31} \mathrm{P} \mathrm{NMR}(\mathrm{CDCl} 3$; $121 \mathrm{MHz}): \delta=+36.0$ (s). ${ }^{1} \mathrm{H}$ NMR $(\mathrm{CDCl} 3 ; 300 \mathrm{MHz}): \delta=1.46$ (s, 3H, CH3), 1.49 (s, $3 \mathrm{H}, \mathrm{CH} 3), 1.53(\mathrm{~s}, 3 \mathrm{H}, \mathrm{CH} 3), 1.56(\mathrm{~s}, 3 \mathrm{H}, \mathrm{CH} 3), 7.19(\mathrm{~d}, 1 \mathrm{H}, J(\mathrm{H}, \mathrm{H})=8.1 \mathrm{~Hz}$, CHaromatic), 7.27-7.73 (m, 20H, CHaromatic), $7.99(\mathrm{~d}, 1 \mathrm{H}, J(\mathrm{H}, \mathrm{P})=70.8 \mathrm{~Hz},=\mathrm{CH})$, 8.01-8.07 (m, 3H, CHaromatic). ${ }^{13} \mathrm{C}$ NMR (CDCl3, $\left.75 \mathrm{MHz}\right): \delta=26.9$ (s, CH3), 27.0 (s, CH3), 27.1 (s, $C H 3$ ), 27.2 (s, $C H 3$ ), 46.9 (s, Cfluorenyl), 47.0 (s, Cfluorenyl), 119.7 (s, CHaromatic), 120.3 (s, CHaromatic), 120.5 (s, CHaromatic), 120.6 (s, CHaromatic), 120.9 (d, J(C,P) = 9.5 Hz, CHaromatic), 122.7 (s, CHaromatic), 123.2 (s, CHaromatic), $126.8(\mathrm{~d}, J(\mathrm{C}, \mathrm{P})=8.6 \mathrm{~Hz}, C$ Haromatic), 127.1 (s, CHaromatic), 127.3 (s, CHaromatic), 127.6 (s, CHaromatic), 128.1 (s, CHaromatic), 128.3 (s, CHaromatic), 128.6 (s, CHaromatic), 128.7 (s, CHaromatic), 129.1 (d, $J(\mathrm{C}, \mathrm{P})=12.0 \mathrm{~Hz}, C$ Haromatic), 130.2 (s, CHaromatic), 130.9 (d, J(C,P) $=83.4 \mathrm{~Hz}, C$ ipso $), 131.4(\mathrm{~d}, J(\mathrm{C}, \mathrm{P})=11.3 \mathrm{~Hz}$, CHaromatic), 132.5 (s, CHaromatic $\left.{ }^{2}\right), 138.3$ (s, Caromatic), 138.5 (d, J(C,P) = 8.6 Hz, Caromatic), 138.7 (s, Caromatic), 139.6 (s, Caromatic), 139.8 (d, J(C,P) = 16.9 Hz, Caromatic), 140.1 (s, Caromatic), 141.2 (s, Caromatic), 141.7 (d, J(C,P) = 77.0 Hz, $C \mathrm{sp} 2), 144.0(\mathrm{~d}, J(\mathrm{C}, \mathrm{P})=12.4 \mathrm{~Hz},=C \mathrm{H}), 154.1(\mathrm{~d}, J(\mathrm{C}, \mathrm{P})=8.0 \mathrm{~Hz}, C$ aromatic $), 154.4$ (s, Caromatic), $155.6(\mathrm{~d}, J(\mathrm{C}, \mathrm{P})=78.5 \mathrm{~Hz}, C \mathrm{sp} 2), 1 C$ Haromatic and $3 \mathrm{C}_{\text {aromatic }}$ are not observed, may overlap. HR-MS (ESI, $\mathrm{CHCl}_{3} / \mathrm{MeOH}, 50 / 50, \mathrm{v} / \mathrm{v}, \mathrm{m} / \mathrm{z}$ ): $[\mathrm{M}+\mathrm{Na}]^{+}$calcd for $\mathrm{C}_{46} \mathrm{H}_{37} \mathrm{ONaP}$, 659.24797; found 659.2476. Anal. Calcd for $\mathrm{C}_{46} \mathrm{H}_{37} \mathrm{OP}$ (636.76): $\mathrm{C}$ 86.77, H 5.86, found: C 86.59, H 5.67.

Synthesis of $\mathbf{3 e}$ : The procedure is similar as for $\mathbf{3 a}$. The crude product was purified by chromatography on silica (Petroleum ether/AcOEt, 2/1). The recovered fraction was crystallized in $\mathrm{Et}_{2} \mathrm{O}$ and hexane to get a yellow solid (277 mg, $0.55 \mathrm{mmol}, 58 \%$ yield). ${ }^{31} \mathrm{P}$ NMR $(\mathrm{CDCl} 3 ; 121 \mathrm{MHz}): \delta=+36.4(\mathrm{~s}) .{ }^{1} \mathrm{H}$ NMR $(\mathrm{CDCl} 3 ; 300 \mathrm{MHz}): \delta=7.03-$ $7.71(\mathrm{~m}, 23 \mathrm{H}, \mathrm{CH}$ aromatic), $8.49(\mathrm{~d}, 1 \mathrm{H}, J(\mathrm{H}, \mathrm{P})=72.0 \mathrm{~Hz},=\mathrm{CH}), 8.63(\mathrm{~d}, 1 \mathrm{H}, J(\mathrm{H}, \mathrm{H})$ $=8.4 \mathrm{~Hz}, \mathrm{CHaromatic}) .{ }^{13} \mathrm{C} \mathrm{NMR}(\mathrm{CDCl} 3 ; 100 \mathrm{MHz}): \delta=125.4$ (s, CHaromatic), 125.6 (s, CHaromatic), 125.8 (s, CHaromatic), 126.1 (s, CHaromatic), 126.2 (s, CHaromatic), 126.6 (s, CHaromatic), 127.5 (d, J(C,P) = 9.4 Hz, CHaromatic), 127.7 (s, CHaromatic), 128.3 (s, CHaromatic), 128.5 (s, CHaromatic), 128.6 (s, CHaromatic), 128.7 (s, CHaromatic), 128.8 (s, CHaromatic), 128.9 (s, CHaromatic), 129.0 (s, CHaromatic), 
129.1 (s, CHaromatic), 129.5 (d, $J(\mathrm{C}, \mathrm{P})=3.6 \mathrm{~Hz}$, Caromatic), $130.6(\mathrm{~d}, J(\mathrm{C}, \mathrm{P})=79.8$ Hz, Cipso), 130.7 (s, CHaromatic), 131.1 (d, J(C,P) = 11.6 Hz, CHaromatic), 131.7 (s, Caromatic), 132.3 (s, CHaromatic), 133.9 (s, Caromatic), 134.1 (s, Caromatic), 136.8 (d, $J(\mathrm{C}, \mathrm{P})=10.7 \mathrm{~Hz}$, Caromatic), 138.5 (s, Caromatic), $140.0(\mathrm{~d}, J(\mathrm{C}, \mathrm{P})=17.5 \mathrm{~Hz}, C \mathrm{sp} 2)$, $144.7(\mathrm{~d}, J(\mathrm{C}, \mathrm{P})=82.1 \mathrm{~Hz}, C \mathrm{sp} 2), 146.5(\mathrm{~d}, J(\mathrm{C}, \mathrm{P})=12.5 \mathrm{~Hz},=C \mathrm{H}), 157.2(\mathrm{~d}, J(\mathrm{C}, \mathrm{P})=$ $73.4 \mathrm{~Hz}, C \mathrm{sp} 2$ ), One Caromatic are not observed, may overlap. HR-MS (ESI, MeOH, $m / z):[\mathrm{M}+\mathrm{Na}]^{+}$calcd for $\mathrm{C}_{36} \mathrm{H}_{25} \mathrm{OPNa}, 527.15407$; found 527.1538; Anal. Calcd for $\mathrm{C}_{36} \mathrm{H}_{25} \mathrm{OP}$ (504.16): C 85.70, H 4.99, found: C 85.95, H 5.24.

Synthesis of $\mathbf{3 f}$ : The procedure is similar as for $\mathbf{3 a}$. The crude product was purified by chromatography on silica (Petroleum ether/AcOEt, 4/1, v/v). The recovered fraction was crystallized in $\mathrm{Et}_{2} \mathrm{O}$ and hexane to get a yellow solid $(315 \mathrm{mg}, 0.44 \mathrm{mmol}, 46 \%$ yield). ${ }^{31} \mathrm{P}$ NMR (CDCl3; $\left.121 \mathrm{MHz}\right): \delta=+34.6$ (s). ${ }^{1} \mathrm{H}$ NMR $(\mathrm{CDCl} 3 ; 300 \mathrm{MHz}):{ }^{1} \mathrm{H}$ NMR (CDCl3; $300 \mathrm{MHz}): \delta=0.85\left(\mathrm{t}, 3 \mathrm{H}, J(\mathrm{H}, \mathrm{H})=6.6 \mathrm{~Hz}, \mathrm{CH}_{3}\right), 0.87(\mathrm{t}, 3 \mathrm{H}, J(\mathrm{H}, \mathrm{H})=$ $\left.6.6 \mathrm{~Hz}, \mathrm{CH}_{3}\right), 1.31-1.35\left(\mathrm{~m}, 8 \mathrm{H}, \mathrm{CH}_{2}\right), 1.81-1.83\left(\mathrm{~m}, 4 \mathrm{H}, \mathrm{CH}_{2}\right), 4.22(\mathrm{t}, 4 \mathrm{H}, J(\mathrm{H}, \mathrm{H})=$ $\left.7.2 \mathrm{~Hz}, \mathrm{~N}-\mathrm{CH}_{2}\right), 7.13-7.59$ (m, $\left.18 \mathrm{H}, \mathrm{CH}_{\text {aromatic }}\right), 7.80$ (s, $\left.1 \mathrm{H}, \mathrm{CH}_{\text {aromatic }}\right), 7.90$ (d, $1 \mathrm{H}$, $J(\mathrm{H}, \mathrm{P})=71.7 \mathrm{~Hz},=\mathrm{CH}) 7.97-8.18\left(\mathrm{~m}, 5 \mathrm{H}, \mathrm{CH}_{\text {aromatic }}\right) .{ }^{13} \mathrm{C} \mathrm{NMR}(\mathrm{CDCl} 3 ; 75 \mathrm{MHz}): \delta=$ $13.9\left(\mathrm{~s}, \mathrm{CH}_{3}\right), 13.9\left(\mathrm{~s}, \mathrm{CH}_{3}\right), 22.4\left(\mathrm{~s}, \mathrm{CH}_{2}\right), 22.5\left(\mathrm{~s}, \mathrm{CH}_{2}\right), 28.6\left(\mathrm{~s}, \mathrm{CH}_{2}\right), 28.7\left(\mathrm{~s}, \mathrm{CH}_{2}\right)$, $29.3\left(\mathrm{~s}, \mathrm{CH}_{2}\right), 29.4\left(\mathrm{~s}, \mathrm{CH}_{2}\right), 43.2\left(\mathrm{~s}, 2 \mathrm{CH}_{2}\right), 108.5$ (s, CHaromatic), 108.7 (s, CHaromatic), 109.0 (s, CHaromatic), 109.2 (s, CHaromatic), 118.9 (s, CHaromatic), 119.5 (s, CHaromatic), 119.6(s, CHaromatic), 120.7(s, CHaromatic), 120.8 (s, CHaromatic), 121.3 (s, CHaromatic), 122.5 (d, J(C,P) = 6.0 Hz, Caromatic), 122.7 (s, Caromatic), 122.8 (s, Caromatic), 123.0 (s, Caromatic), 123.3 (s, Caromatic), 125.0 (d, $J(\mathrm{C}, \mathrm{P})=9.2 \mathrm{~Hz}, C$ Haromatic), 125.7 (s, CHaromatic), 126.2 (s, CHaromatic), 127.2 (s, CHaromatic), 127.9 (s, CHaromatic), 128.5 (s, CHaromatic), 129.0 (d, $J(\mathrm{C}, \mathrm{P})=11.9 \mathrm{~Hz}$, CHaromatic), 130.3 (s, CHaromatic), 130.8 (d, J(C,P) = $8.8 \mathrm{~Hz}$, Caromatic), 131.5 (d, $J(\mathrm{C}, \mathrm{P})=11.2 \mathrm{~Hz}, C$ Haromatic $), 131.7(\mathrm{~d}, J(\mathrm{C}, \mathrm{P})=83.5 \mathrm{~Hz}, C$ ipso $), 132.2(\mathrm{~s}$, CHaromatic), 138.9 (s, Caromatic), 140.4 (s, Caromatic), 140.5 (d, J(C,P) = 80.1 Hz, $C \mathrm{sp} 2), 140.6(\mathrm{~d}, J(\mathrm{C}, \mathrm{P})=17.3 \mathrm{~Hz}, C \mathrm{sp} 2), 140.8$ (s, Caromatic), 141.0 (s, Caromatic), $141.9(\mathrm{~d}, J(\mathrm{C}, \mathrm{P})=12.9 \mathrm{~Hz},=C \mathrm{H}), 155.2(\mathrm{~d}, J(\mathrm{C}, \mathrm{P})=78.1 \mathrm{~Hz}, C \operatorname{sp} 2)$. One Caromatic are not observed, may overlap. HR-MS (ESI, $\mathrm{CH}_{2} \mathrm{Cl}_{2} / \mathrm{MeOH}, 10 / 90$, v/v, $\left.m / z\right)$ : $[\mathrm{M}+\mathrm{Na}]^{+}$ calcd for $\mathrm{C}_{50} \mathrm{H}_{47} \mathrm{ON}_{2} \mathrm{PNa}$, 745.33182; found 745.3316; Anal. Calcd for $\mathrm{C}_{50} \mathrm{H}_{47} \mathrm{ON}_{2} \mathrm{P}$ (722.34): C 83.07, H 6.55, found: C 83.25, H 6.24 .

\section{Acknowledgements}

This work is supported by the Ministère de la Recherche et de l'Enseignement Supérieur, the Institut Universitaire de France, the CNRS, the Région Bretagne, ChinaFrench associated international laboratory in "Functional Organophosphorus Materials" and COST CM0802 (Phoscinet). National Natural Science Foundation (21072179, 21272218) of China, Henan Science and Technology Department (114300510007), and Zhengzhou Science and Technology Department (131PYSGZ204). The authors are grateful to C. Lescop for X-ray diffraction studies and to J. Troles for the DSC measurements. (Supporting Information is available online from Wiley InterScience or from the author).

[1] a) C. W. Tang, S. A. VanSlyke, Appl. Phys. Lett. 1987, 51, 913; b) C. Adachi, S Tokito, T. Tsutsui, S. Saito, Jpn J. Appl. Phys. 1988, 27, 1269; c) C. W. Tang, S. A. VanSlyke, C. H. Chen, J. Appl. Phys. 1989, 65, 3610; d) B. W. D’Andrade, S R. Forrest, Adv. Mater. 2004, 16, 1585; e) K. T. Kamtekar, A. P. Monkman, M. R. Bryce, Adv. Mater. 2010, 22, 572; f) B. W. D'Andrade, Nat. Photonics. 2007, 1, 33; g) M. C. Gather, A. Köhnen, K. Meerholz Adv. Mater. 2011, 23, 233.

[2] a) P.-A. Bouit, A. Escande, R. Szücs, D. Szieberth, C. Lescop, L. Nyulászi, M Hissler, R. Réau, J. Am. Chem. Soc. 2012, 134, 6524 ; b) Y. Ren, W. H. Kan, M A.Henderson, P. G. Bomben, C. P. Berlinguette, V. Thangadurai, T. Baumgartner, J. Am. Chem. Soc. 2011, 133, 17014; c) E. Deschamps, L. Ricard, F. Mathey Angew. Chem. Int. Ed. Engl. 1994, 33, 1158; d) Y. Matano, M Nakashima, H. Imahori,. Angew. Chem. Int. Ed. 2009, 48, 4002; e) K. Yavari, S.
Moussa, B. Ben Hassine, P. Retailleau, A. Voituriez, A. Marinetti, Angew. Chem. Int. Ed. 2012, 51, 6748; f) W. Weymiens, M. Zaal, J. C. Slootweg, A. W. Ehlers, K. Lammertsma Inorg. Chem. 2011, 50, 8516; g) Y. Dienes, M. Eggenstein, T. Kárpáti, T. C. Sutherland, L. Nyulászi, T. Baumgartner, Chem. Eur. J. 2008, 14, 9878, h) A. Fukazawa, M. Hara, T. Okamoto, E.-C. Son, C. Xu, K. Tamao, S. Yamaguchi, Org. Lett. 2008, 10, 913; i) A. Fukazawa, H. Yamada, S. Yamaguchi, Angew. Chem. Int. Ed. 2008, 47, 5582.

[3] a) H. Chen, W. Delaunay, L. Yu, D. Joly, Z. Wang, J. Li, Z. Wang, C. Lescop, D. Tondelier, B. Geffroy, Z. Duan, M. Hissler, F. Mathey, R. Réau, Angew. Chem. Int. Ed. 2012, 51, 214; b) D. Joly, D. Tondelier, V. Deborde, W. Delaunay, A. Thomas, K. Bhanuprakash, B. Geffroy, M. Hissler, R. Réau Adv. Funct. Mater. 2012, 22, 567; c) D. Joly, D. Tondelier, V. Deborde, B. Geffroy, M. Hissler, R. Réau New. J. Chem., 2010, 8, 1603; d) O. Fadhel, M. Gras, N. Lemaitre, V. Deborde, M. Hissler, B. Geffroy, R. Réau Adv. Mat., 2009, 21, 1261; e) H. Su, O. Fadhel, C.-J. Yang, T.-Y. Cho, C. Fave, M. Hissler, C.-C. Wu, R. Réau, J. Am. Chem. Soc., 2006, 128, 983.

[4] Phosphorus-Carbon Heterocyclic chemistry : the rise of a new domain, ed F. Mathey, Pergamon 2001

[5] a) A. Marinetti, J. Fischer, F. Mathey, F. J. Am. Chem. Soc. 1985, 107, 5001; b) N. H. Tran Huy, L. Richard, F. Mathey, Organometallics 1988, 7, 1791; c) H. Jun, R. J. Angelici, Organometallics 1993, 12, 4265; d) L. Weber, O. Kaminski, H.-G. Stammler, B. Neumann, Organometallics 1995, 14, 581; e) L. Dupuis, N. Pirio, P. Meunier, A. Igau, B. Donnadieu, J.-P. Majoral, Angew. Chem. Int. Ed. 1997, 36, 987 ; f) N. Pirio, S. Bredeau, L. Dupuis, P. Schütz, B. Donnadieu, A. Igau, J.-P. Majoral, J.-C. Guillemin, P. Meunier, Tetrahedron 2004, 60, 1317 ; g) M. Zablocka, J. M. Majoral, Current Org. Chem., 2007, 11, 49.

[6] a) A. Hengefeld, R. Nast, Chem. Ber. 1983, 116, 2035; b) I. P. Beletskaya, V. V. Afanasiev, M. A. Kazankova, I. V. Efimova, Org. Lett. 2003, 23, 4309; c) V. V. Afanasiev,. I. P. Beletskaya, M. A. Kazankova, I. V. Efimova, M.-U. Antipin, Synthesis 2003, 18, 2835.

[7] M. A. A. El Bayoumi, F. M. A. Halim J. Chem. Phys. 1968, 48, 2536.

[8] a) N. Matsusue, S. Ikame, Y. Suzuki, H. Naito, Appl. Phys. Lett., 2004, 85, 4046. b) H. I. Baek, C. Lee, J. Appl. Phys. 2008, 103, 054510.

[9] a) H. Choukri, A. Fischer, S. Forget, S. Chénais, M.-C. Castex, D. Adès, A. Siove, B. Geffroy, Appl. Phys. Lett. 2006, 89, 183513. b) E.I. Haskal, Synthetic Metals 1997, 91, 157.

[10] J. N. Demas, G. A. Crosby, J. Phys. Chem. 1971, 75, 991

[11] Z. Otwinowski, W. Minor In Methods in Enzymology, (Ed.: C.W. Carter, Jr. \& R.M. Sweet), New York:Academic Press, 1997, 276, 307.

[12] A. Altomare, M.C. Burla, M. Camalli, G. Cascarano, C. Giacovazzo, A. Guagliardi, A. G. G. Moliterni, G. Polidori, R. Spagna, J. of Applied Cryst. 1999, 32,115

[13] International Tables for X-ray Crystallography, vol C, Ed. Kluwer, Dordrech, 1992

[14] Gaussian 03, Revision C.02, M. J. Frisch, G. W. Trucks, H. B. Schlegel, G. E. Scuseria, M. A. Robb, J. R. Cheeseman, J. A. Montgomery, Jr., T. Vreven, K. N. Kudin, J. C. Burant, J. M. Millam, S. S. Iyengar, J. Tomasi, V. Barone, B. Mennucci, M. Cossi, G. Scalmani, N. Rega, G. A. Petersson, H. Nakatsuji, M. Hada, M. Ehara, K. Toyota, R. Fukuda, J. Hasegawa, M. Ishida, T. Nakajima, Y. Honda, O. Kitao, H. Nakai, M. Klene, X. Li, J. E. Knox, H. P. Hratchian, J. B. Cross, C. Adamo, J. Jaramillo, R. Gomperts, R. E. Stratmann, O. Yazyev, A. J. Austin, R. Cammi, C. Pomelli, J. W. Ochterski, P. Y. Ayala, K. Morokuma, G. A. Voth, P. Salvador, J. J. Dannenberg, V. G. Zakrzewski, S. Dapprich, A. D. Daniels, M. C. Strain, O. Farkas, D. K. Malick, A. D. Rabuck, K. Raghavachari, J. B. Foresman, J. V. Ortiz, Q. Cui, A. G. Baboul, S. Clifford, J. Cioslowski, B. B. Stefanov, G. Liu, A. Liashenko, P. Piskorz, I. Komaromi, R. L. Martin, D. J. Fox, T. Keith, M. A. Al-Laham, C. Y. Peng, A. Nanayakkara, M. Challacombe, P. M. W. Gill, B. Johnson, W. Chen, M. W. Wong, C. Gonzalez, and J. A. Pople, Gaussian, Inc., Wallingford CT, 2004 
[15] a) A. Hengefeld, R. Nast, Chem. Ber. 1983, 116, 2035; b) I. P. Beletskaya, V. V. Afanasiev, M. A. Kazankova, I. V. Efimova, Org. Lett. 2003, 23, 4309; c) V. V.

Synthesis 2003, 18, 2835. 
